\title{
Russian Federation: Financial Sector Stability Assessment Update
}

This Financial Sector Stability Assessment Update on the Russian Federation was prepared by a staff team of the International Monetary Fund as background documentation for the periodic consultation with the member country. It is based on the information available at the time it was completed on July 11, 2008. The views expressed in this document are those of the staff team and do not necessarily reflect the views of the government of Russian Federation or the Executive Board of the IMF.

The policy of publication of staff reports and other documents by the IMF allows for the deletion of market-sensitive information.

\author{
Copies of this report are available to the public from \\ International Monetary Fund • Publication Services \\ $70019^{\text {th }}$ Street, N.W. • Washington, D.C. 20431 \\ Telephone: (202) 623-7430 • Telefax: (202) 623-7201 \\ E-mail: publications@imf.org Internet: http://www.imf.org
}

\section{International Monetary Fund Washington, D.C.}




\title{
INTERNATIONAL MONETARY FUND
}

\author{
RUSSIAN FEDERATION
}

\section{Financial System Stability Assessment Update}

\author{
Prepared by the Monetary and Capital Markets and European Departments
}

Approved by Christopher Towe and Poul M. Thomsen

July 11, 2008

This report presents the conclusions of the IMF-World Bank FSAP Update mission that visited Moscow in May and October 2007. The mission team comprised David Hoelscher (team leader, IMF), Lalit Raina (deputy team leader, World Bank), Sylvie Bossoutrot, Michael Edwards, Joaquin Gutierrez, John Hegarty, and Rodney Lester (all World Bank), Jonathan Katz (World Bank consultant), Alexandre Chailloux, Marina Moretti, Elina Ribakova, Paul Ross, Andrew Tiffin, and Jan Willem van der Vossen (all IMF). Neven Mates (IMF resident representative) provided valuable support to the team.

The mission held discussions with the Governor of the Central Bank of Russia (CBR), the Deputy Minister of Finance, and senior officials from the CBR and the Ministry of Finance, the Federal Financial Market Service, the Financial Sector Insurance Service, the Deposit Insurance Agency, the stock exchanges, and representatives from state-owned and private financial institutions. The main findings include:

- Indicators of bank soundness and performance are broadly favorable but credit risk poses a challenge over the medium term and capitalization should rise to support continued banking sector development.

- $\quad$ The system has weathered the global credit crunch that began in mid-2007 yet the funding model is coming under strain as the turmoil in global markets continues.

- $\quad$ The CBR has responded effectively to the recent liquidity pressures, but its tools for maintaining financial sector stability and problem bank resolution could be strengthened.

- $\quad$ Banking supervision has improved but supervision should become increasingly risk-based.

- $\quad$ Capital markets have grown dramatically in recent years but remain highly concentrated.

FSAPs are designed to assess the stability of the financial system as a whole and not that of individual institutions. They have been developed to help countries identify and remedy weaknesses in their financial sector structure, thereby enhancing their resilience to macroeconomic shocks and cross-border contagion. FSAPs do not cover risks that are specific to individual institutions such as asset quality, operational or legal risks, or fraud. 


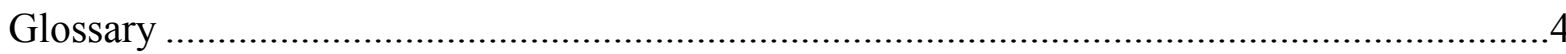

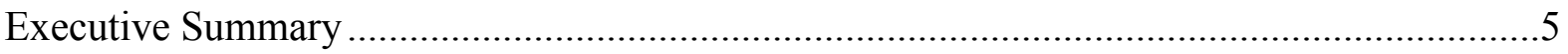

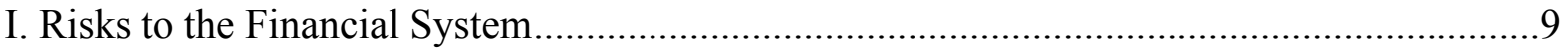

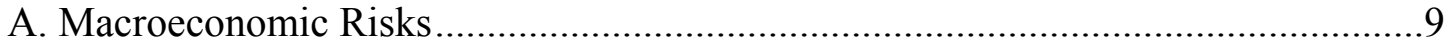

B. The Financial System and its Risk Exposures ………….........................................11

II. Strengths and Vulnerabilities of the Financial Sector......................................................16

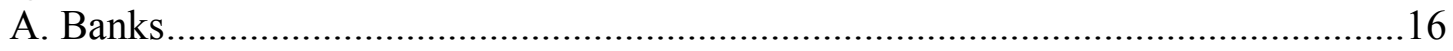

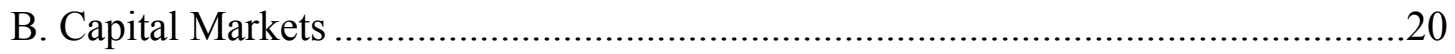

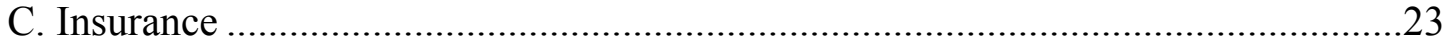

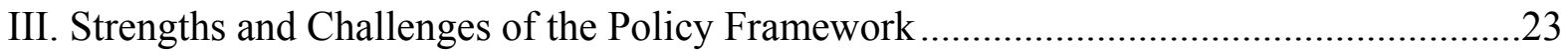

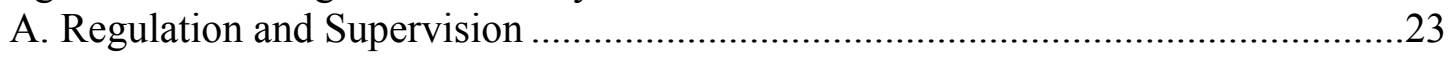

B. Problem Bank Resolution and Safety Nets ............................................................2

C. Anti-Money Laundering and Combating the Financing of Terrorism.....................28

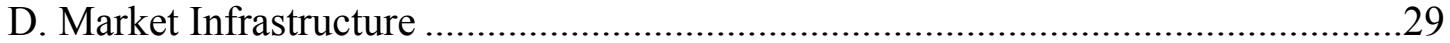

Figures

1. Economic Developments and Outlook, 1994-2012 …................................................10

2. Key Features of the Financial System ……………...................................................12

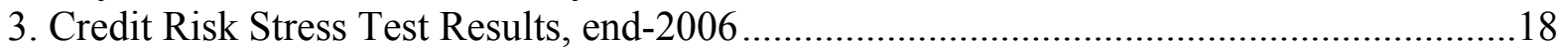

4. Market Risk Stress Test Results, end-2006 …………................................................19

5. Liquidity Risk Stress Test Results, end-2006 ...............................................................19

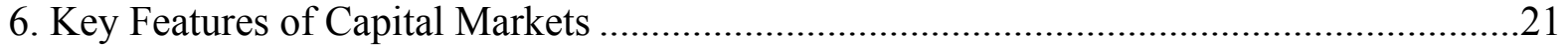

Boxes

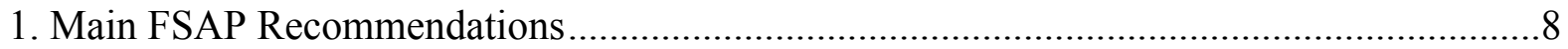

Annex

Observance of Financial Sector Standards and Codes-Summary Assessment of Compliance with the Basel Core Principles of Effective Banking Supervision

Appendices

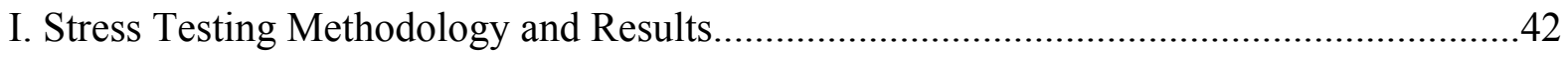

II. Macroeconomic and Financial Sector Indicators ..............................................................4

III. Implementation of Recommendations from the 2003 FSAP ............................................55

Appendix Tables

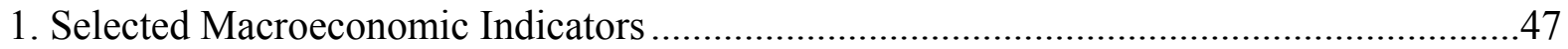




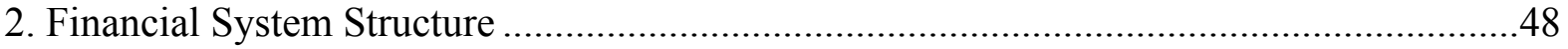

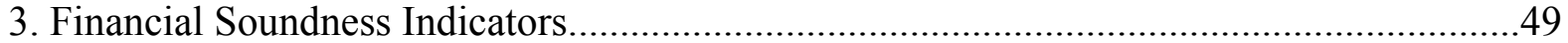

4. Summary Balance Sheet of the Banking System...........................................................50

5. Insurance Penetration and Density in Selected Markets, 2006........................................51

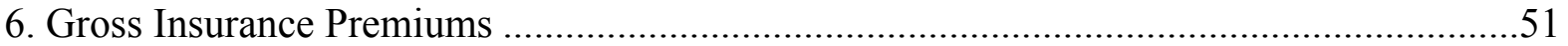




\section{GLOSSARY}

$\begin{array}{ll}\text { AML/CFT } & \text { Anti-Money Laundering and Combating the Financing of Terrorism } \\ \text { BCP } & \text { Basel Core Principles of Effective Banking Supervision } \\ \text { BIS } & \text { Bank for International Settlements } \\ \text { BL } & \text { Law on Banks and Banking Activity } \\ \text { CBL } & \text { Statute of the Central Bank or the Law on the Central Bank } \\ \text { CBR } & \text { Central Bank of Russia } \\ \text { CPs } & \text { Core Principles } \\ \text { DIA } & \text { Deposit Insurance Agency } \\ \text { Duma } & \text { State Duma (lower house of parliament) } \\ \text { FFMS } & \text { Federal Financial Markets Service } \\ \text { FIU } & \text { Financial Intelligence Unit } \\ \text { FSAP } & \text { Financial Sector Assessment Program } \\ \text { FSIS } & \text { Financial Sector Insurance Service } \\ \text { GDP } & \text { Gross Domestic Product } \\ \text { IAS } & \text { International Accounting Standards } \\ \text { IFRS } & \text { International Financial Reporting Standards } \\ \text { IOSCO } & \text { International Organization of Securities Commissions } \\ \text { IPOs } & \text { Initial Public Offerings } \\ \text { MICEX } & \text { Moscow Interbank Currency Exchange } \\ \text { MOF } & \text { Ministry of Finance } \\ \text { MOU } & \text { Memorandum of Understanding } \\ \text { NPF } & \text { Nonstate pension funds } \\ \text { NPL } & \text { Nonperforming loan } \\ \text { OTC } & \text { Over the counter } \\ \text { RAS } & \text { Russian Accounting Standards } \\ \text { ROSC } & \text { Report on Standards and Codes } \\ \text { RTS } & \text { Russian Trading System Stock Exchange } \\ \text { SROs } & \text { Self-regulatory organization } \\ \text { ROA } & \text { Return on assets } \\ \text { ROE } & \text { Return on equity } \\ \end{array}$




\section{EXECUTIVE SUMMARY}

Since the 2003 FSAP, the Russian financial system has strengthened and deepened. This improvement reflected favorable macroeconomic conditions, growing consumer confidence, investor demand, and the strengthening of the legal and regulatory framework. Banks still dominate the system but capital markets have deepened and an insurance sector has begun to emerge.

The system has weathered the global credit crunch that began in mid-2007, but the banks' funding model poses an immediate challenge as global markets remain weak. With retail deposits concentrated in the largest state bank and thin domestic capital markets, some banks are dependent on foreign sources for funding and substantial funding concentration remains in the smaller banks. This segmentation, along with structural weaknesses in the interbank market, exposes the system to potentially serious liquidity problems should private confidence weaken or foreign appetite for Russian exposure decline. Thus far, banks have been able to meet debt service through syndicated loans and rolling over maturing debt.

The CBR has responded effectively to the liquidity pressures, but its tools for financial sector stability could be strengthened. Crisis management techniques could be strengthened, by (i) more intensive monitoring of the liquidity positions and projections of individual banks' liquidity needs; (ii) discussions with bank managers and boards of directors about their likely response to further illiquidity; and (iii) development of bank-by-bank contingency plans. The Ministry of Finance could introduce cash management systems that, in coordination with the CBR, would help smooth the volatility of the overnight interest rate associated with tax collections.

Credit risk, arising because of the rapid credit expansion, poses the greatest challenges. Credit growth to households has been rapid and this is high-risk segment given the poor information on borrowers and untested risk management systems of banks. While strengthening profitability, this expansion in lending could lead to a buildup of unrecognized credit risk.

Exposure to market risk has grown in some banks. While market risk is less of a concern than credit and liquidity risk, as securities holdings remain moderate in relation to capital levels. Banks maintain long open positions in foreign exchange but the relatively small size of unhedged positions limits potential exposure to currency risk. Interest rate risk is potentially significant for some banks although data limitations prevent a detailed analysis. Increased exposure to market risk — particularly by state banks and foreign banksunderscores the need to improve market risk monitoring.

Banks' resilience to shocks may be overstated by reported financial data. Reported capital ratios have fallen since 2003 as a result of strong asset growth. Moreover, these ratios could be overstated because of weaknesses in loan classification and provisioning. Adoption 
of less discretionary provisioning rules by banks could reduce reported capital, in some cases by almost half. As raising capital in the current environment might be a challenge given the reduction in global risk appetite and a likely decline in profits, a phased program of capital strengthening combined with close monitoring of its implementation is warranted.

The CBR's monitoring of systemic risk has improved but could be further strengthened by improved internal coordination. The CBR has devoted extensive efforts to strengthening its financial stability analysis capabilities. However, this work is spread between the off-site supervisory department and the research department, with limited collaboration between the two. Better coordination by these two units, along with more fluid transfer of information from on-site supervisors including the development of stress tests based on macroeconomic scenarios, would improve the capacity of CBR to monitor the buildup of risks and vulnerabilities at a systemic level.

Notwithstanding these efforts data limitations impede analysis and monitoring of risks. Lack of information on related party exposures and beneficial ownership limits credit risk assessment. Interest rate risk is significant in some banks but data limitations prevent a consistent evaluation of market risk for the financial sector. A programmed strengthening of data collection is warranted.

Banking supervision has improved since the 2003 FSAP but challenges remain. The CBR supervisory staff has been strengthened and the introduction of CBR accounting rules, based on International Reporting Standards (IFRS) principles in January 2008, will improve management information and disclosure. Full implementation of IFRS, however, still requires passage of the law on consolidation, currently before the Duma. The CBR has issued guidance on corporate governance and internal controls and made progress on anti-money laundering and combating the financing of terrorism (AML/CFT) issues. At the same time, areas for strengthening were identified. Regulations on loan-loss provisioning hinder a clear view on the real level of bank capitalization. The principal focus of supervision remains formal compliance with quantitative limits that constrain early identification of real financial risks and potentially slow supervisory response to such risk. Opaque beneficial ownership of banks and nontransparent group affiliations also persist, making it difficult to assess intra-group exposures and their associated risks.

The problem bank resolution framework has been effective in dealing with smaller banks but may not be sufficient to resolve medium-sized or larger banks. The CBR would benefit from having the authority to intervene in weak banks at an early stage, thereby containing resolution costs in larger, more complex cases and limiting disruption to creditors, including depositors. Such corrective action and a broader range of options to sell the franchise of a failed bank to interested investors could be important resolution tools. In that context, efforts are warranted to broaden public awareness of the details of deposit insurance, including a description of coverage, to avoid any public confusion in the event of a failure. 
The size of the equity market has grown dramatically in recent years but remains highly concentrated. The market remains concentrated in the ten largest companies and continues to be constrained by a small free float that ranges between 20 and 35 percent. Better disclosure by companies and market participants, stronger and more secure market infrastructure, and further development of nonbank financial institutions will help the market grow further and increase free float.

\section{Since 2003, the regulatory and legal framework for capital markets has been}

strengthened. The Federal Financial Markets Service (FFMS) was created with an expanded regulatory authority to cover derivatives markets, collective investment schemes, and pension funds, as well as responsibility for disclosure of mergers, acquisitions, and tender offers of public companies. The FFMS has moved to strengthen regulation through issuance of regulations covering collective investment schemes and, effective January 2008, established higher capital adequacy requirements for market participants. The strengthening of the regulatory and legal framework is welcome, but further strengthening is needed and the FFMS requires additional resources to discharge effectively its broader responsibilities.

\section{The insurance sector, while underdeveloped, is expanding rapidly making the} regulatory challenges significant. Supervision by the Financial Sector Insurance Service (FSIS) has improved considerably since the previous assessment, and weak insurers are being closed. However, the FSIS's ability to attract and retain necessary staff to cope with the growing complexity of the industry and continued consolidation is constrained. In addition, the insurance law is missing critical elements including powers to respond to emergency situations, apply rules on ownership changes, and determine the fit and proper status of controllers, directors, and officers. 


\section{Box 1. Main FSAP Recommendations}

\section{Immediate stability priorities}

1. Begin tightening loan-loss provisioning standards to foster appropriate levels of bank capitalization ( $\mid 22)$.

2. Review banks' liquidity estimates and develop contingency plans (that conform to CBR recommendations under preparation, $\llbracket 14-19)$.

3. Continue to develop the lender-of-last-resort function by broadening the range of nonmarketable assets eligible as collateral, along with appropriate supervisory oversight and prudential safeguards to avoid excessive access to emergency liquidity (\$53).

4. Further strengthen risk-based supervision and build off-site capacity through developing the CBR's financial stability analysis function by introducing stress tests based on macroeconomic scenarios $(\boldsymbol{\Phi} \mid 26,37-41)$.

\section{Medium-term structural priorities}

5. Strengthen transparency and disclosure; improve data quality and availability for the financial sector including through IFRS implementation, better corporate governance and disclosure of securities transactions ( $₫ 30-32$, $42-43,49,62-63)$.

6. Introduce cash management by the Ministry of Finance, in coordination with the CBR, in order to smooth the intra-monthly volatility of the overnight interest rate resulting from monthly tax collections ( $₫ 60)$.

7. Establish the legal concept of "beneficial owner" to address weaknesses in bank licensing, large exposures, consolidated supervision, and overall market transparency $(\uparrow 30,42-43,49)$.

8. Provide for development of consolidated supervision of banking groups based on appropriate methodologies ( $\mid 42-43)$.

9. Strengthen the remedial action and bank resolution frameworks by introducing prompt corrective actions and giving the CBR powers for early intervention, including the sale of failing banks ( $₫ 54-56$ ).

10. Strengthen prudential oversight of the securities markets by implementing pending legal and regulatory reforms and strengthening the capacities of the FFMS ( $\mid 46-48)$.

11. Increase enforcement authority against insider trading/market manipulation (\$46).

12. Improve market transparency through the mandatory listing of active stocks, separate disclosure of repurchase transactions, and continuing to improve reporting of over the counter (OTC) transactions ( $₫$ 32).

13. Implement regular oversight of SROs (\$51).

14. Create a central clearing and settlement system, and rationalize and automate custodian arrangements ( $\$ 64-66)$.

15. Upgrade the insurance law to include fit and proper criteria ( $₫ 50)$.

16. Strengthen FSIS regulatory authority and capacity, including by allowing it to issue technical directives and emergency actions $(\boldsymbol{\Phi 5 2 )}$.

17. Bring minimum capital of insurance companies to EU standards ( $₫ 50)$. 


\section{RiSKS TO THE FinANCIAL SYSTEM}

\section{A. Macroeconomic Risks}

1. Given robust economic growth, balance of payments and fiscal surpluses, and substantial international reserves, the Russian economy is well positioned to deal with macroeconomic shocks. High oil prices, as well as improved macroeconomic management, have contributed significantly to Russia's favorable situation which have attracted substantial foreign investors' interest, boosted domestic incomes, and spurred credit growth.

2. Growing demand pressures are raising inflationary concerns. GDP growth exceeded 8 percent in 2007, well above most estimates of potential (Appendix Table 1). In the context of a highly managed exchange rate (a de facto peg against a composite) and strong capital inflows, monetary growth has been rapid. Annual broad money growth reached about 50 percent by end 2007. These developments helped reverse a downward trend for inflation, which rose to almost 12 percent year-on-year in December; above the end-year target of 8 percent.

\section{Without a renewed focus on macroeconomic stabilization, Russia's real} exchange rate may overshoot its sustainable path. Although the real exchange rate continues to appreciate and import growth accelerates, export volumes remain healthy, competitiveness is not yet a major concern; and Russia's real exchange rate is broadly in line with fundamentals. However, with double-digit inflation, a planned fiscal relaxation over the near term, and a largely accommodating monetary stance, the risk that excess demand might push the pace of real appreciation too far is growing.

\section{Looking further ahead, as oil prices stabilize, Russia's twin surpluses are likely} to be reversed, leaving the economy increasingly dependent on international capital markets. The continued pace of import growth is expected to cause a narrowing of the current account surplus, which may become a deficit as early as in 2011 (Figure 1). Given the government's current spending plans, the fiscal surplus also will fall as oil-related tax revenues level off. These trends will mean that a prolonged disruption of international financial markets could make financing the balance of payments difficult. 
Figure 1. Economic Developments and Outlook, 1994-2012

Russia's impressive growth...

Contributions to GDP growth

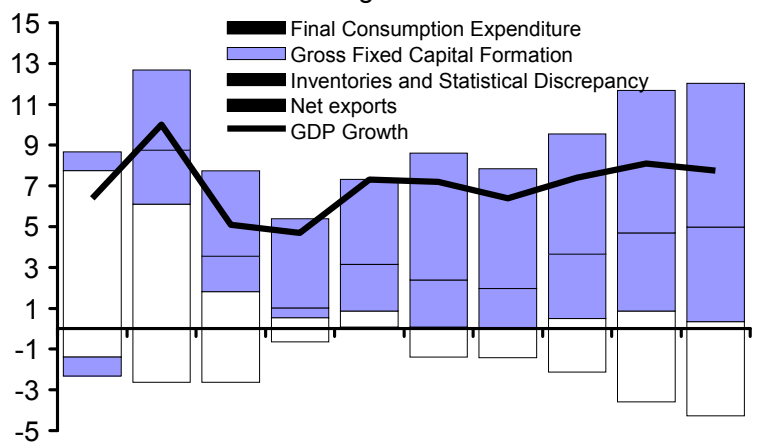

199920002001200220032004200520062002008 1/

... and improved access to foreign funds.

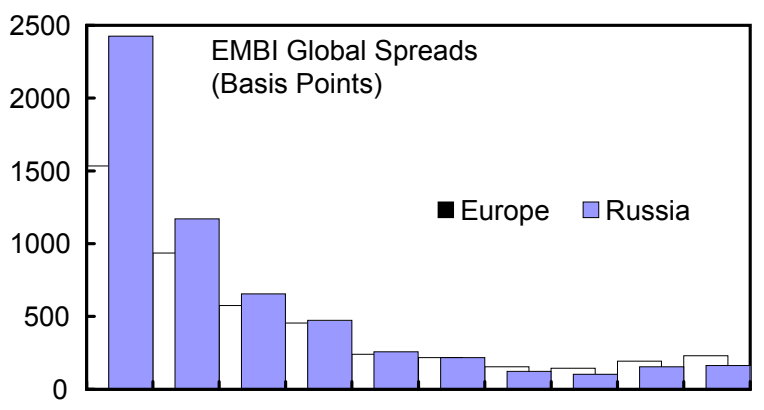

199920002001200220032004200520062002008 1/

...fiscal margins will narrow sharply....

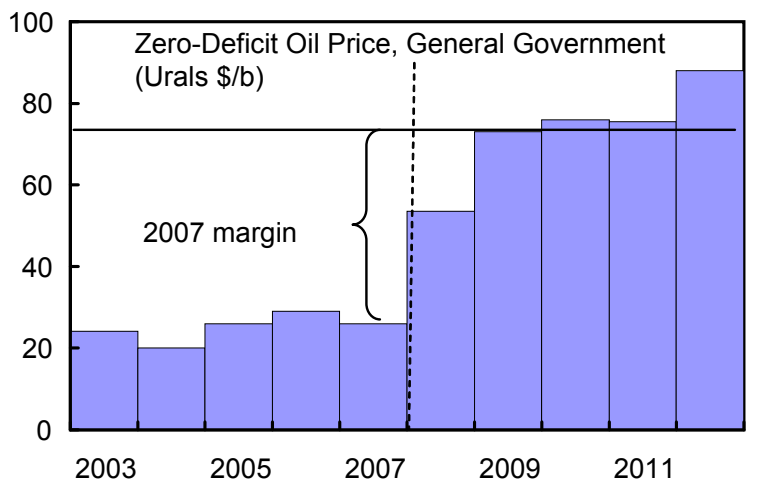

...reflects dramatic terms-of-trade gains...

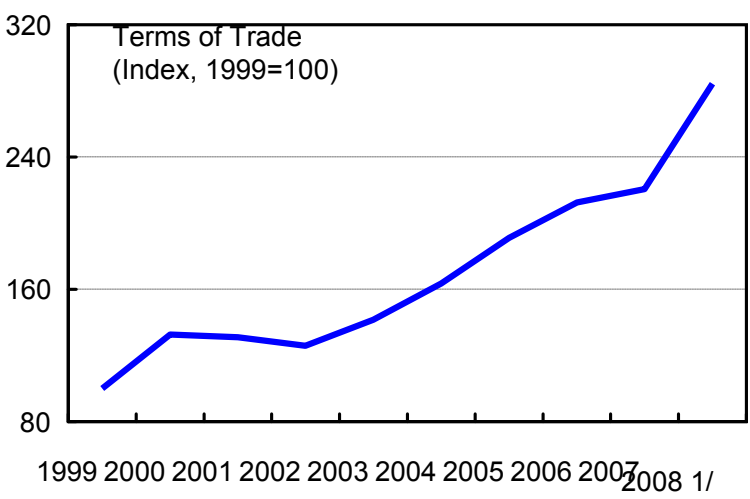

But, as oil prices stabilize,....

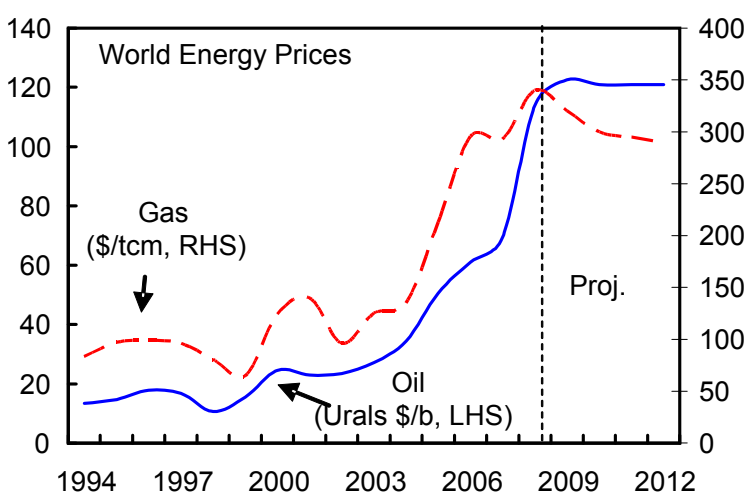

....and the current-account surplus will unwind.

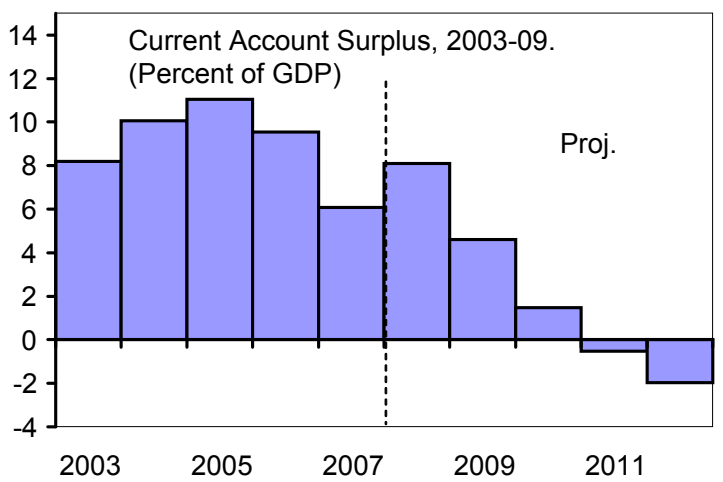

Source: WEO, national authorities, Bloomberg, staff calculations.

1/ Projections for 2008, except for EMBI spreads which were as of end-May 2008. 


\section{B. The Financial System and its Risk Exposures}

5. The Russian financial system is small by international standards and is dominated by banks. Total assets of banks were 54 percent of GDP at end-2007, compared with over 200 percent in France, Germany, and Japan. Commercial banks are the main component of the Russian financial sector, comprising about 90 percent of total financial assets (Appendix Table 2). Insurance companies, pension funds, and mutual funds account for a roughly equal share of the remainder.

6. The banking system is dominated by state-owned banks. State-owned banksaccounting for over one third of total banking assets and nearly 60 percent of household deposits - are dominated by six large banks. Large Russian private banks account for over one third of banking assets and increasingly rely on foreign borrowing. Foreign-controlled banks account for about 17 percent of banking assets and have a low share of deposits and finance their credit expansion with foreign borrowing. Small Russian banks and nonbank credit institutions account for about ten percent of banking system assets and report high capital-to-asset ratios but low profitability.

7. Russian capital markets have expanded in recent years but the sector remains small and vulnerable. Total assets of the nonbank financial institutions, including equity, pension and insurance funds, amount to only 9 percent of total financial sector assets or 5.8 percent of GDP (see Figure 2). Factors constraining the expansion of this market include lack of a broad investor base, relatively underdeveloped life insurance and pension companies, and lack of comprehensive information disclosure by issuers.

8. The insurance sector is a small but growing portion of the financial sector. At end-2006, total insurance assets amounted to only 1 percent of GDP. Moreover, insurance density, measured both as per capita nonlife premium and per capita life premium, were considerably below countries with similar levels of GDP (Appendix Table 5). Life insurance premiums have collapsed in recent years due to strong regulatory action to reduce tax evasion activities but "real" life premiums are beginning to show rapid growth from a very small base. Nonlife premium income has grown rapidly - by 21 percent in 2006-due to the introduction of motor third party insurance and favorable tax treatment for certain liability premiums (Appendix Table 6).

\section{Credit risk}

\section{Rapid growth in credit to corporates and households in Russian banks has} increased banks' risk exposures. Bank assets have grown at annual rates of about 40 percent since 2004 (Figure 2). Loan portfolios increased almost 50 percent in both 2006 and 2007. While these rates of growth are abating, the credit and macroeconomic risks they entail warrant continued close monitoring by the authorities. 
Figure 2. Key Features of the Financial System

Banks dominate the system...

Financial system assets, 2006

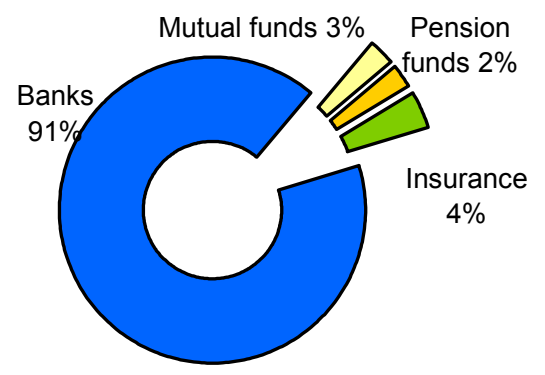

The system has grown rapidly...

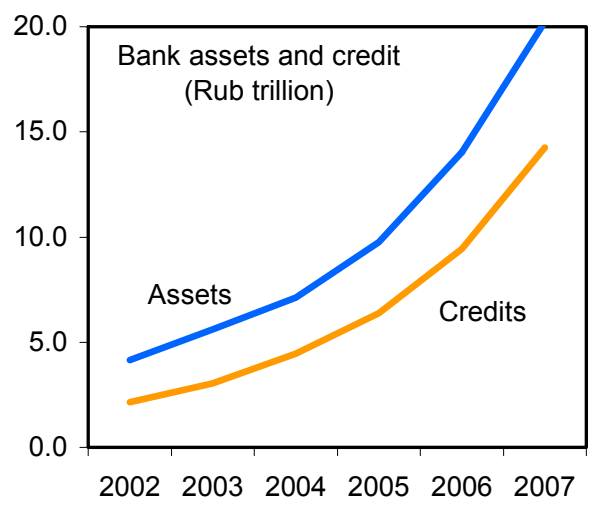

Lending boom supported high margins...

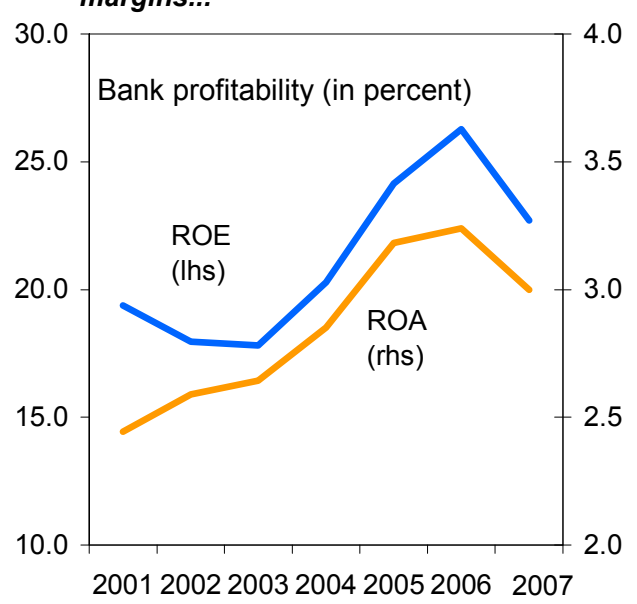

Source: CBR and Fund staff estimates.

\section{... and the sector is highly concentrated \\ Banking assets, December 2007}

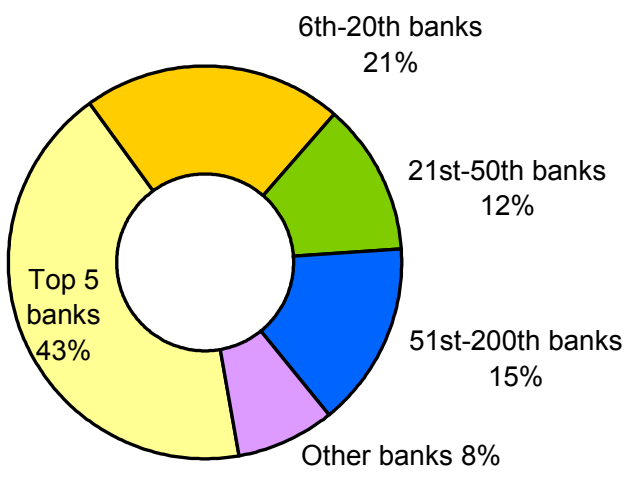

... but remains relatively small

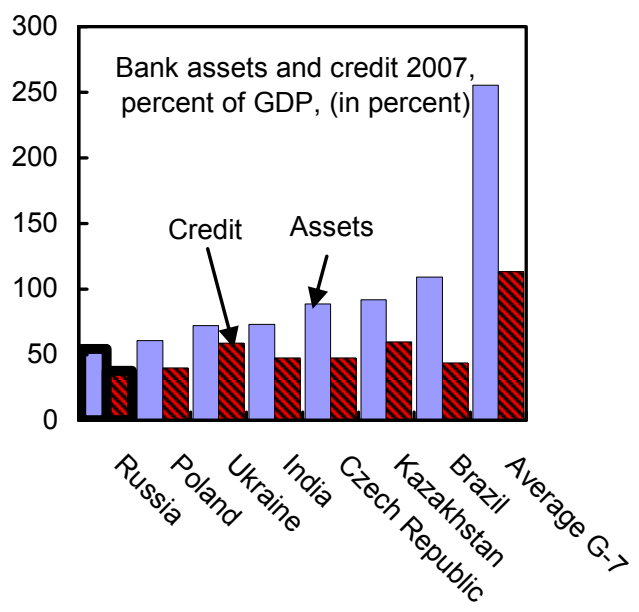

... but asset quality coming under pressure

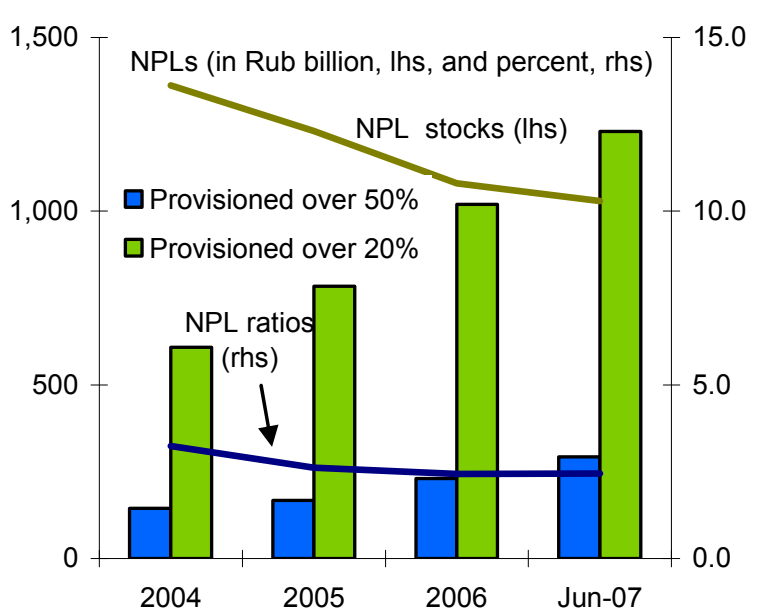


10. Household credit—a high-risk segment—has grown quickly. Household loans increased by 57 percent in 2007 (after growing by 75 percent in 2006 and 91 percent in 2005 albeit from a low base) and now represent one quarter of total customer credits. Such a rapid increase makes good credit assessment difficult and may lead to a buildup of unrecognized credit risk. NPLs for households have increased recently and consumer loan performance is untested during an economic downturn. However, consumer loans do represent diversification away from corporate lending and the low aggregate indebtedness of households provides some comfort on their debt repayment capacity, ${ }^{1}$ although the loans could create problems in the event of erosion in household incomes. Moreover, banks' ability to check on individual borrowers' creditworthiness remains limited in the absence of a fully functioning creditor information system.

11. Within the consumer segment, rapid growth in mortgage lending is a particular concern. Mortgage loans increased five-fold by end-2006 and 65 percent in 2007 and the share of this segment in total consumer loan portfolios has grown to 25 percent. There are wide differences across banks in underwriting standards for these loans and loan-to-value ratios - reportedly reaching over 90 percent in some cases. If real estate prices were to decline, mortgage lending could become an area of heightened risk for banks.

12. Foreign exchange lending to households is a material, though declining, source of risk to banks. Loan dollarization dropped from 35 percent four years ago to 27 percent of all loans at end-2007. While most dollar lending is to nonresidents or exporters, 13 percent of credit to resident individuals is still denominated in foreign currency, making banks vulnerable to exchange rate-induced credit risk.

13. Loan concentration is high and possibly underreported. Exposure to the five largest borrowers exceeds 50 percent of capital for over half of the banking system in terms of both assets and number of banks. While limits are set on exposure to both single borrowers and interrelated groups, the latter are difficult to monitor, reflecting opaque ownership and beneficial owners' structures and limited legal authority of supervisors, discussed below. Credit to shareholders is also high in some banks, exceeding the limit of 50 percent of capital and may be underreported.

\section{Liquidity risk}

\section{Despite expanding funding options, liquidity in the banking system remains}

highly segmented. Retail deposits are concentrated in one bank, substantial funding concentration remains in the smaller banks, and some of the large-and medium-sized banks increasingly reliant on international funding. The problem of segmentation is compounded by

\footnotetext{
${ }^{1}$ Household debt-to-income ratios have been growing very rapidly in the last few years but remained at a modest 12 percent at end-2006, up from 3 percent at end-2003.
} 
structural weaknesses in the interbank market and generally uneven risk management capacities across banks.

15. Retail deposits remain a relatively limited source of funding for the system as a whole, although private banks' market share is increasing. Household deposits represent, on average, 30 percent of bank liabilities but are concentrated in the state-owned banks (mostly Sberbank). Partly reflecting the introduction of deposit insurance, large private and foreign banks have been able to increase their retail funding. While deposit maturities have lengthened in recent years, pursuant to the Civil Code, all deposits are callable.

16. Concentration of corporate deposits remains an issue for smaller banks, and withdrawals by just a few customers could result in liquidity problems. For some small banks, the twenty largest depositors can account for over half of customer funding. The experience of 2004 shows that corporate deposits can be more volatile than household deposits in the event of shocks to confidence.

17. Substantial external funding poses a risk to the banking system. Over

the last few years, banks have borrowed significant amounts abroad, with nonresident funding equal to 24 percent of liabilities at end-2007, up from 11 percent at end-2004. ${ }^{2}$ Bank borrowing contributed to the growth of Russia's external debt (see table). Dependence on foreign funding varies considerably across banks and is highest for large private banks (exceeding 70 percent of liabilities in some cases) and foreign banks.

\footnotetext{
${ }^{2}$ Foreign borrowing and bond issuance exceeded \$40 billion in 2006 and 2007.
} 


\section{The turbulence in international markets has highlighted the system's exposure} to refinancing risks. The increase in global risk aversion since mid-2007 slowed the flow and raised the cost of foreign funding to the banking system, exposing some banks to potential refinancing difficulties. Since mid-2007, access to the Eurobond market has remained limited and domestic bond market volume has decreased in late 2007 and early 2008. Syndicated and bilateral loans were used by some banks to rollover maturing debt. While forthcoming repayments in 2008-2009 are not insignificant (see figure), most banks are not expected to experience liquidity shortages. However, credit growth is likely to slow as domestic sources of funding are

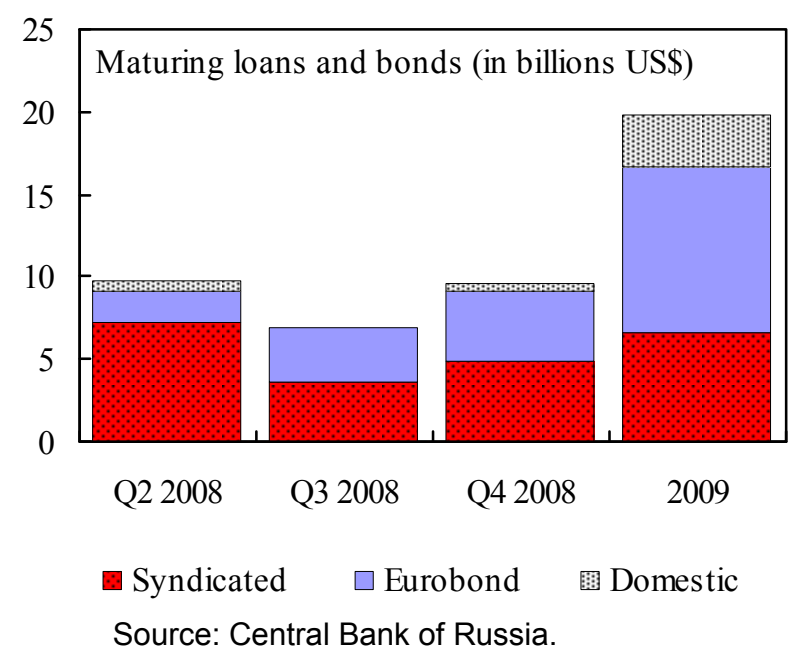
not sufficient to compensate for lower external funds.

19. Groups of banks will face different challenges in maintaining adequate funding levels. The largest banks are likely to face a slowdown in foreign inflows and higher borrowing costs but appear to have adequate resources to weather the current market turbulence. State-controlled banks either have a strong deposit base or can access international markets at lower cost due to the perceived state-guarantee. Private mediumsized banks may face difficulties maintaining access to international markets. Some of these banks have already started to curb their credit growth. The prospects for the smaller regional banks that are closely tied to local corporate clients will depend on the pace of economic activity.

\section{Market risk}

20. Exposure to market risk has grown with the deepening of capital markets and the increased sophistication of banks, but data limitations hinder accurate assessment. Securities portfolios, representing about 13 percent of assets at end-2007, are dominated by corporate bonds (although equity holdings can be significant) and expose banks to potential losses in the event of adverse movements in equity and bond prices. Interest rate risk can be significant for some banks given the limited use of hedging instruments, although data limitations prevent a detailed analysis (see discussion on stress testing, below). ${ }^{3}$

21. Banks maintain long open positions in foreign exchange. Foreign-denominated assets include both securities and loans. However, for most of the period 2004-2006 the net

\footnotetext{
${ }^{3}$ Banks do not report interest rate risk for the banking book-one of the core risks to be considered under Pillar II of Basel II.
} 
open position was small, limiting potential exposure to currency risk (Statistical Appendix Table 3). In 2007, the banks' net open position increased twofold, reflecting a combination of continued growth in foreign exchange lending and a consolidation and repayment of banks' maturing external debt.

\section{STREngthS ANd VULnerabilities Of THE Financial SeCtor}

\section{A. Banks}

\section{Performance}

22. The current environment of rapid growth has supported strong profitability but masks important vulnerabilities. Bank capital has been falling as a share of assets and, although reported capital remains adequate in most banks, ${ }^{4}$ increased capital will be needed to sustain further growth (Appendix Table 3). Moreover, provisioning rules may mask undercapitalization (see below). Bank liquidity has also been declining since 2003, and, as noted earlier, has been further reduced by the turmoil in international markets (Appendix Table 4).

\section{Asset classification and provisioning practices may give an upward bias to} reported capital and profits. With total gross loans increasing faster than classified loans, the NPL ratio declined to 2.6 percent at end-2006 and 2.2 percent at end-2007 but the underlying NPL stock (defined as loans provisioned by over 50 percent) is increasing. Loan classification and provisioning rules were revised in 2004, but several concerns remain: ${ }^{5}$

- $\quad$ Provisioning requirements are set in broad ranges and provide considerable discretion to banks, which determine their own provisioning levels (net of collateral) within the range. Provisions are low (3.4 percent of gross loans) and if banks booked provisions near the upper bound of the range, reported bank capital would be reduced by almost half. ${ }^{6}$

\footnotetext{
${ }^{4}$ Russian banks are subject to a capital adequacy requirement of 10 percent and from January 2007, a minimum absolute capital of EUR 5 million. Only newly established banks are subject to the latter, and as of mid-2007, close to 500 banks (representing less than 2 percent of system's assets) had capital below EUR 5 million.

${ }^{5}$ Regulation 254-P of March 2004 requires that large (individually assessed) loans be classified in five categories based on past-due status and the financial condition of borrowers. Homogeneous loans (mostly to consumers) are classified based on past-due status and provisions. In both cases, NPLs include loans required to be provisioned by over 50 percent (categories IV and V for large loans). Provisions are struck net of collateral (with a 50 percent haircut for lower-quality collateral).

${ }^{6}$ State-owned banks are the most vulnerable to this adjustment, losing almost 60 percent of their end-2006 capital, followed by the large private banks, which would lose close to half of their capital.
} 
- Uncertainties exist about the accuracy of collateral valuation, which complicate the assessment of the value of banks' loan portfolios.

- Loans classified as "doubtful" can be treated as "performing" if the bank determines the borrower to be sound. ${ }^{7}$ Expanding the definition of NPLs to include doubtful loans would increase the NPL ratio to 10.3 percent.

Tightening of this system, reducing discretion, would be helpful at a time when global markets require robust capital levels. Implementation should be phased to prevent undue financial burden.

\section{Rapid credit growth has sustained strong earnings but profitability is coming} under pressure. High interest rates on the fastest-growing credit segments, along with low deposit rates, resulted in relatively high spreads by international comparison. Increased competition in lending, however, is compressing margins and lowering returns during 2007. Going forward, funding pressures are likely to increase the cost of funding, resulting in banks retrenching their lending to remain liquid, and are likely to result in lower profits. Banks' desire to strengthen their

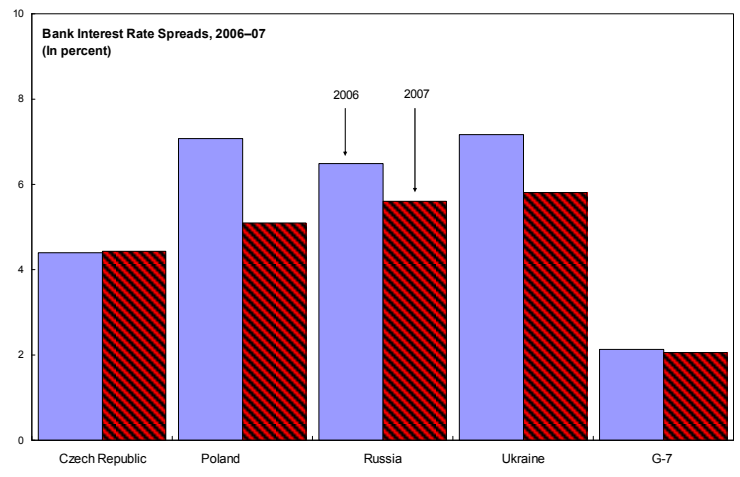
retail base as a substitute for foreign funding will also tend to increase deposit rates, further depressing margins.

\section{Risk management techniques}

25. The quality of banks' risk management is improving but varies significantly. The largest banks have moved away from relationship-based transactions, brought internal procedures closer to accepted international practice, but are challenged by a lack of data and qualified staff. For market and liquidity risks, banks have longer data series encompassing periods of stress. However, many institutions have not incorporated market risk management into decision making. Beyond the top 200 banks, managers are only beginning to recognize the need for risk management. As with their international counterparts, banks are struggling to define sound practices in the area of operational risk.

\section{Risk management is limited by a lack of data, especially on smaller borrowers.} Credit bureaus, introduced in 2004, are growing in number, but the information they collect

\footnotetext{
${ }^{7}$ Current regulations allow banks to classify overdue loans as performing if arrears lasted 6-30 days and occurred in the last 180 days.
} 
is limited and not widely used. The CBR's Central Catalogue of Credit Histories allows each bank to set up its own database and does not provide incentives for data sharing. Moreover, the data included in credit bureaus may be limited as the borrowers must authorize inclusion of each loan in the data base.

\section{Stress tests}

\section{A number of stress tests were performed to evaluate banks' potential resilience}

to large but plausible shocks. The tests evaluated the impact of single factor shocks on bank capital using the CBR's existing model. ${ }^{8}$ The stress tests focused on single factor shocks based on end-2006 data. Tests included deterioration in credit quality, liquidity withdrawals, and fluctuations in the exchange rate and securities prices. A macroeconomic scenario, including an oil shock, was not developed, reflecting data limitations and the need for further work to establish the impact of macroeconomic variables on the financial system. The use of single factor stress tests and lack of macro scenario raises concerns about the robustness of the stress test results - particularly as interactions of shocks can magnify (or dampen) their impact on the real economy - and constrains analysis risks, vulnerabilities, and exposures.

\section{The stress tests report that credit risk is the main concern for Russian banks:}

- A credit risk shock-defined as an increase in NPLs (loans classified in categories IV and V) to 13.7 percent from 10.8 percent (based on experience during the period 1998 to $2006^{9}$ ) — would reduce the system's capital by about half, and many banks would fall below the minimum capital requirement although no bank would become insolvent (Figure 3).

Figure 3. Credit Risk Stress Test Results, end-2006
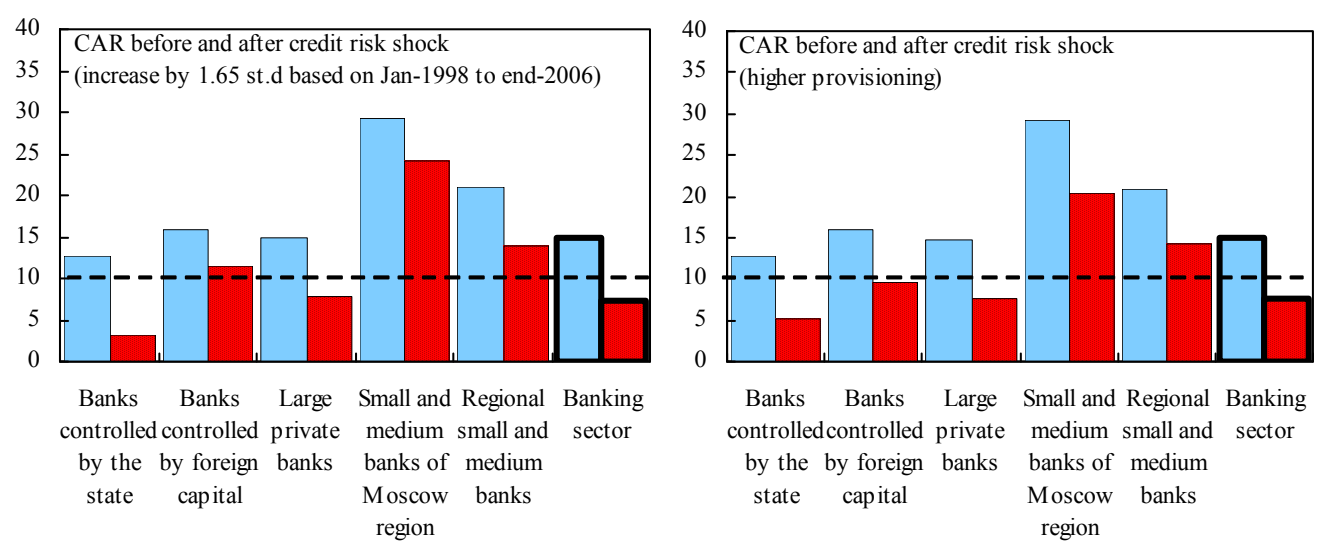

\footnotetext{
${ }^{8}$ The appendix on stress testing discusses in greater detail the specific shocks and their magnitude, results, and provides recommendations to strengthen further stress testing.

${ }^{9}$ This represents an increase of 1.7 standard deviations. Source: CBR and IMF calculations.
} 
- A combined market risk shock - a 15 percent devaluation, 30 percent fall in the value of equities, and 20 percent fall in bond prices - would reduce the system's capital by about six percentage points, largely reflecting large banks' exposure to bond price risk. Interest rate risk at different maturities on the trading book and interest rate risks on the banking book were not assessed because of insufficient data (Figure 4).

Figure 4. Market Risk Stress Test Results, end-2006
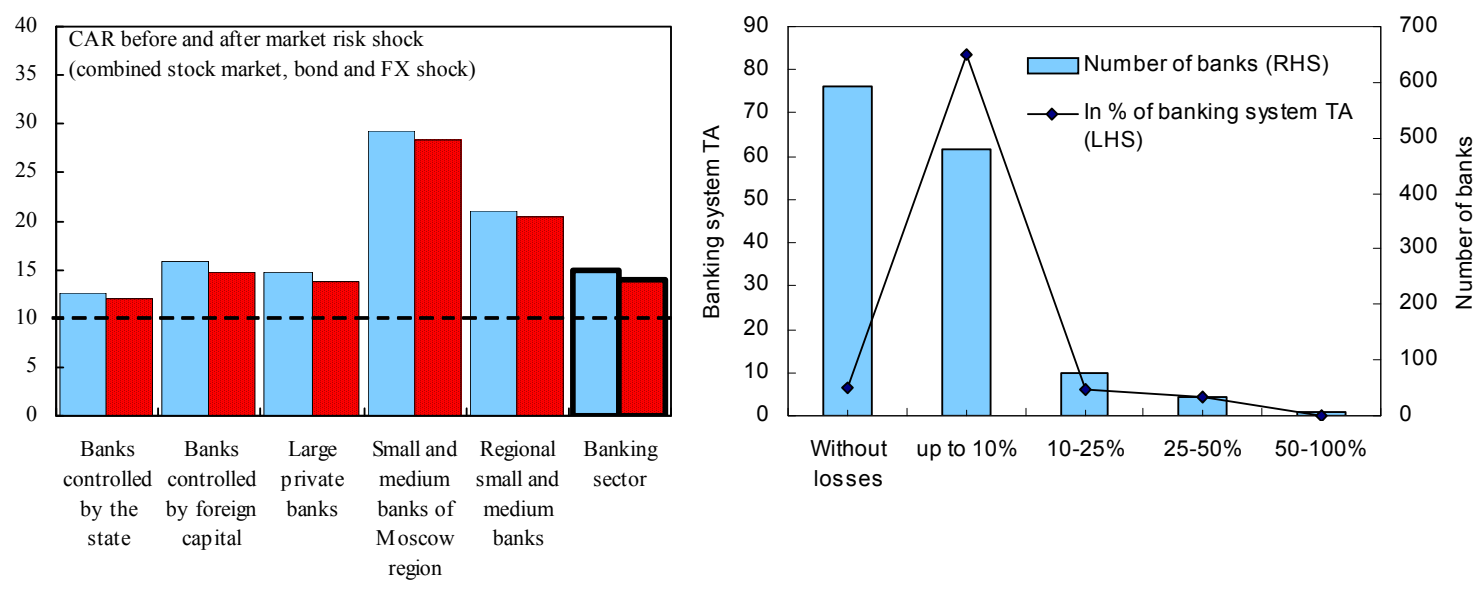

Source: CBR and IMF staff calculations.

- $\quad$ Although a liquidity shock arising from deposit withdrawals would not cause a group of banks to become insolvent, it would reduce capital significantly, especially for medium and small banks. The liquidity shock assumed was a withdrawal of 20 percent of retail deposits to be met by selling liquid assets at a discount. All banking groups were able to meet such liquidity withdrawals with their own resources. However, the shock leads to a decrease in bank capital by five percentage points on average, while only marginally reduced liquidity ratios. Large banks easily weathered this shock but medium and small banks would suffer a sharp reduction in capital. No group of banks became insolvent (Figure 5).

Figure 5. Liquidity Risk Stress Test Results, end-2006
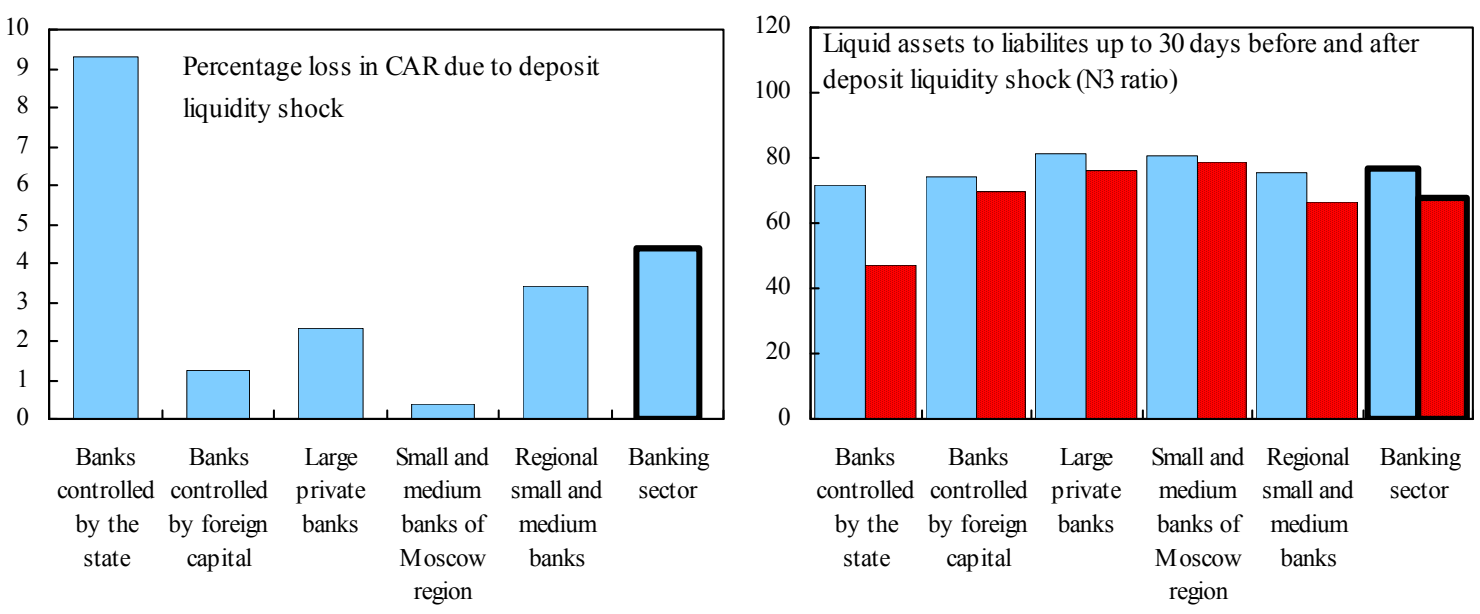

Source: CBR and IMF staff calculations. 
29. As noted above, provisions may be understated. If banks implemented more conservative provisioning policies (i.e., made provisions near the upper end of the broad ranges), reported bank capital would be reduced by almost half. If this lower level of capital were used as a starting point for the stress tests, the credit risk and the market risk tests would eliminate the system's capital, while the liquidity shock would leave the system severely undercapitalized. As noted, the tests used end-2006 data and in early 2007 two large state banks increased their capital through Initial Public Offerings (IPOs), boosting their pre-shock capital ratios from about 13 to 20 percent.

30. To complement the top down stress tests, other tests were conducted with five large banks accounting for $\mathbf{4 0}$ percent of the banking system assets. The exercise focused on the analysis of sensitivity to credit, liquidity, foreign exchange, interest rate, and equity and bond price risks. The tests concluded that credit risk is the key risk to the system, and that exposure to market risk varies dramatically across banks. This exercise also identified interest rate exposure as a potential risk - as some banks might lose 20-30 percent of bank capital in the event of a parallel upward shift in the yield curve by 500 basis points, as well as the need to include in the top down stress tests interest rate risk at different maturities on the trading book and interest rate risks on the banking book. The authorities plan to continue cooperating with banks on bottom-up stress testing.

\section{Data considerations}

31. Data limitations hinder risk monitoring and management in banks. Banks do not report consistently according to IFRS, constraining risk monitoring and limits international comparability of bank balance sheets. In addition, data limitations present a challenge to upgrading risk-oriented bank supervision, and capital market surveillance. Lack of information on credit bureaus, related parties, and beneficial ownership also limits risk assessment. Finally, data on interest rate risks may understate stress testing results.

\section{B. Capital Markets}

32. The equity markets have grown rapidly since 2003, reflecting both economic expansion and changes in domestic regulation. Equity market capitalization rose from approximately 17 percent of GDP at end-2003 to over 100 percent by end-2007 (Figure 6). Capitalization reflected both price appreciation and a sharp increase in company listings. This increase is partly explained by regulations requiring Russian companies to place at least 30 percent of any new stock issues in local markets and imposing a 35 percent limit on overall foreign placements. ${ }^{10}$ Estimates of the free float range from 20-35 percent of market

\footnotetext{
${ }^{10}$ The total world market value of Russian companies (including foreign listings and American and Global Depository Receipts) was $\$ 1.2169$ trillion as of end-June 2007 .
} 
Figure 6. Key Features of Capital Markets

(in percent, unless otherwise noted)
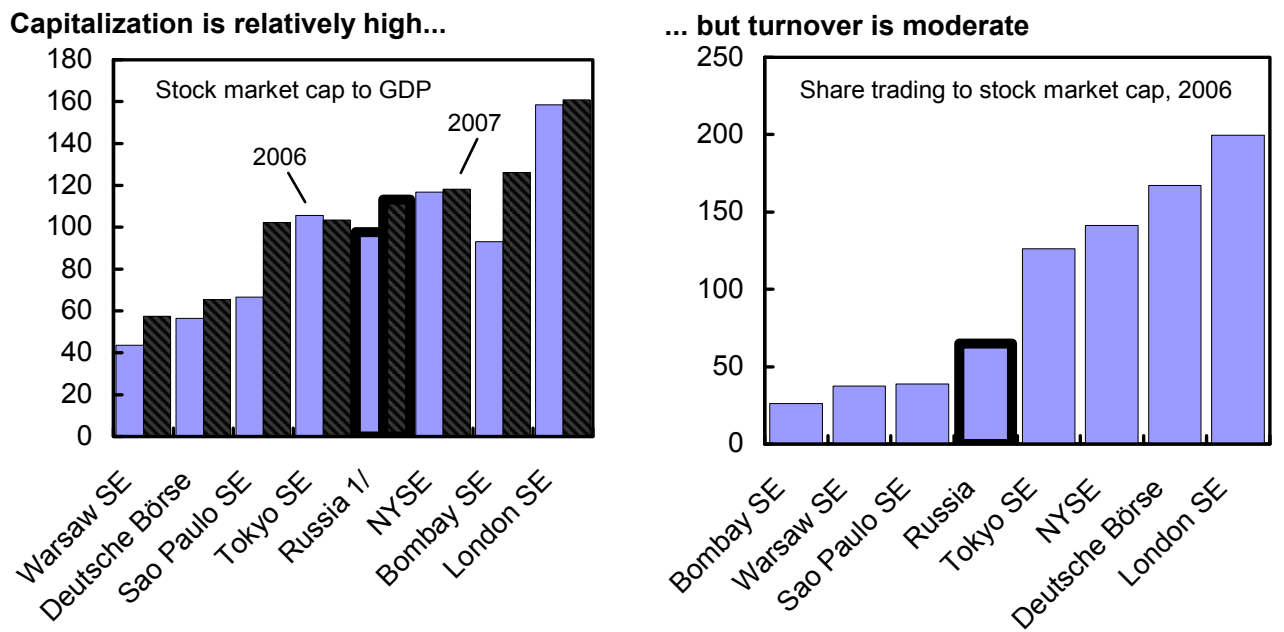

The bond market is small...
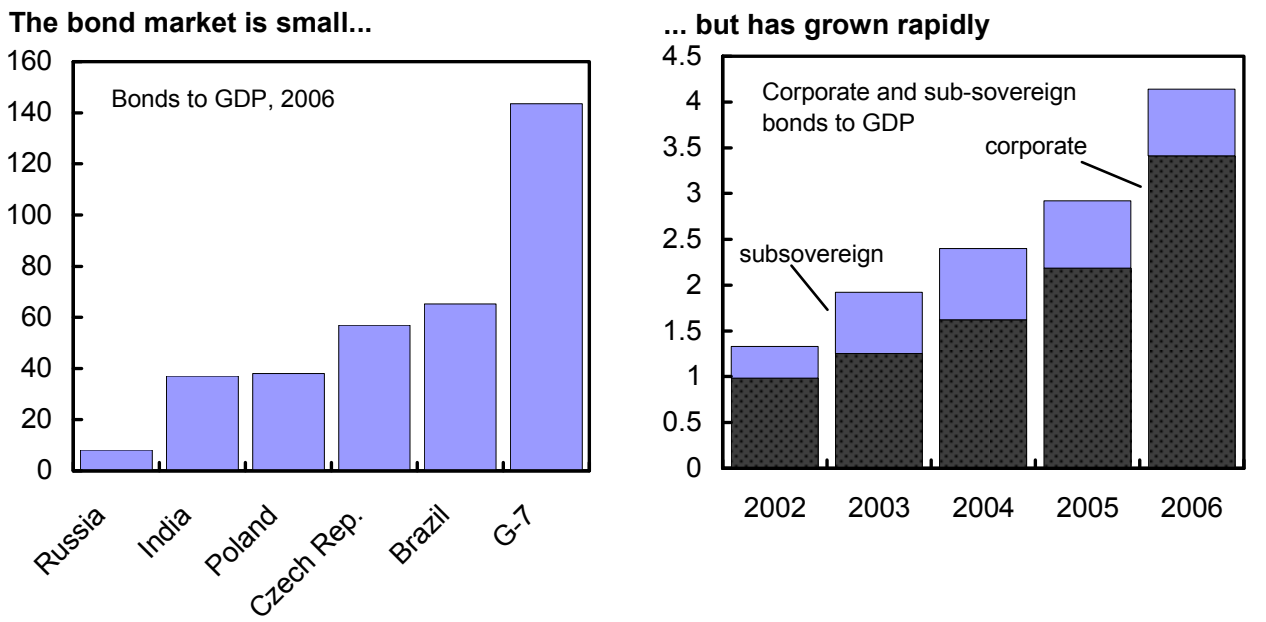

From a low base...
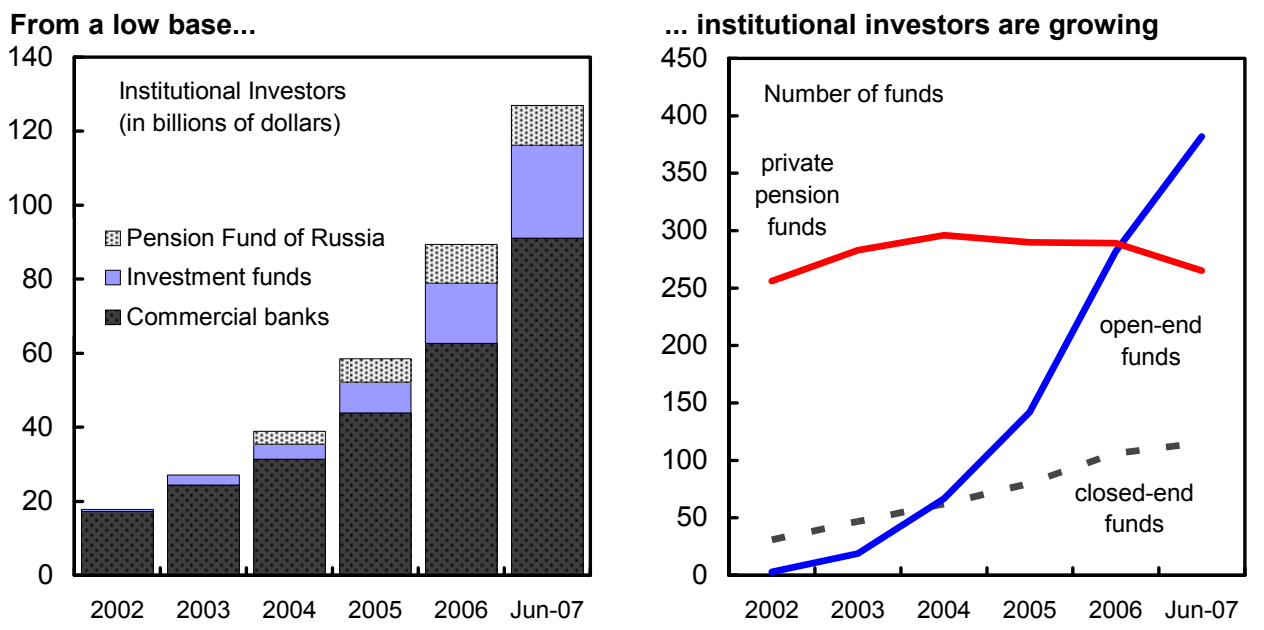

Sources: FFMS, CBR, BIS.

1/ Data for equity market capitalization in Russia for September 2007. 
capitalization but are difficult to confirm because of limitations measuring indirect ownership.

33. Reporting of average daily trading volume of Russian equities should be improved. The Moscow Interbank Currency Exchange (MICEX), which controls approximately 90 percent of reported trading volume, includes equity repo transactions, which are short-term secured loans rather than stock trades, overstating trading volumes by as much as 50-60 percent. Moreover, OTC trading is not measured but may be equal to or greater than daily reported trading. This lack of reported trade information hampers price discovery, undermines governance, and monitoring of insider trading.

34. The corporate bond market is an increasingly important source of financing for mid- and large-sized issuers. Corporate bonds outstanding have grown from $1 / 2$ percent of GDP at end-2000 to 3.5 percent of GDP at end-2006 but remain low by international standards. ${ }^{11}$ The turmoil in international credit markets in mid-2007 led to reductions in the number and size of Russian corporate bond offerings in 2007.

35. Information on the composition and structure of the investor base is limited. The investor base in equities is reported to be split evenly between foreign and domestic investors - the latter primarily high net worth individuals. The foreign investor segment also includes Russian investors investing through off-shore accounts. Russian institutional investors are as yet a relatively small segment of the investing community but they are beginning to play a more visible role. ${ }^{12}$ Banks dominate investment in the domestic bond market.

36. Broker-dealers' capital positions are not updated frequently and clearance and settlement systems have shortcomings. Broker-dealers are required to file monthly capital reports with the FFMS and weekly reports with the exchanges but do not calculate net capital on a daily basis. Moreover, firms are not required to alert the FFMS if their capital is close to the required minimum. The clearance and settlement system is not centralized. The RTS and MICEX are developing central counterparty systems based upon contractual agreements that can be subject to legal challenge, but a central securities and clearance system is needed to mitigate risks (see Section II C below).

37. Private pension funds are underdeveloped but are expected to grow rapidly. There are 265 private pension funds with a total of more than five million contributors and

\footnotetext{
${ }^{11}$ For a discussion of growth in Russia's corporate bond market see Box 4.1 of the September 2005 Global Financial Stability Report.

${ }^{12}$ A requirement that pension funds and mutual funds invest only in "registered" companies prevents these institutions from investing in IPOs until after the offering has been completed and secondary trading begins.
} 
one million pensioners. A general lack of public awareness, a distrust of financial instruments, and tax implications have limited the growth of private funds. The market is dominated by the top 10 occupational funds, which hold approximately 80 percent of total nonstate pension funds (NPF) assets. This sector is expected to grow as employers include pension schemes in compensation packages.

\section{Insurance}

38. The insurance sector's growth and development would benefit from addressing several issues. Foreign insurance companies have a presence in Russia but an easing of entry rules (which limit foreign insurers to 25 percent of capital employed) may be needed to facilitate the sector's expansion. Given the industry growth rate, capital and solvency requirements will need to be strengthened. In particular, a more risk-based solvency regime could be introduced and stronger supervision of asset quality is needed. The application of the VAT on brokers' commission may lead some industrial transactions to be processed abroad to avoid such charges and this discriminatory tax should be reviewed. While brokers should be allowed to receive commission from insurers this should be disclosed to the relevant policyholders.

\section{Strengths and Challenges of the Policy Framework}

\section{A. Regulation and Supervision}

\section{Banking}

39. Banking supervision has been strengthened since the 2003 FSAP but faces a critical challenge in shifting from a rules-based framework to a risk-oriented approach. ${ }^{13}$ The CBR plans to introduce a professional judgment approach that would allow supervision of banks on a more risk-oriented basis through the appointment of bank portfolio managers. ${ }^{14}$ This approach must be built on a common understanding among banks, regulators, and lawmakers on the need to move toward risk-based supervision.

\section{A risk assessment framework will require changes in both approach and}

regulations. The capacity to assess the safety and soundness of their institutions - through a more regular, well-informed dialogue — needs to be enhanced through greater use of sound professional judgment, balanced by appropriate accountability mechanisms. CBR regulations

\footnotetext{
${ }^{13}$ The ROSC on Basel Core Principles of Effective Banking Supervision summarizes the findings of the FSAP update assessment of Banking Supervision (see Annex).

${ }^{14}$ Professional judgment refers to expert or supervisory judgment of CBR staff and relates to the shift that uses greater exercise of supervisory judgment.
} 
and guidance should focus more on risk and less on formal procedures and ratios. This change may require legal and regulatory modifications over the medium term. Required changes include legal protection for supervisors (except for misconduct) and the need to spell out the responsibilities of directors of banks and banking groups.

41. The segmentation of the banking system poses challenges that could be mitigated by recognizing specific bank peer groupings. Given the current segmentation, the same intensity and focus of banking supervision may not be appropriate for all banks. For smaller banks, the assessment should accentuate financial viability, management, transparency, and use more normative risk proxy measures. For larger, more sophisticated banks, the assessment should be more qualitative, discriminate among the main activities that contribute to risks and return, focus on crucial control points, and use more forward-looking risk measures.

\section{Successful implementation of the strategy for a risk-oriented approach will} entail a number of steps. The authorities need to be able to (i) communicate the reasons for the new approach; (ii) compile and disseminate risk management standards; (iii) allocate appropriate staff resources; (iv) implement an accountability framework to monitor effectiveness; (v) adopt viability tests and phased, mandatory strategies for problem banks; and (vi) assure that quality of staff and the responsiveness of the organization are commensurate to this risk-based orientation.

43. Consolidated supervision needs to be strengthened. "Upward consolidation" to supervise a nonbank holding company of a banking group is currently not possible. Further, the CBR has insufficient powers to trace and estimate the risks emanating from the ultimate beneficial owners of a bank and their related parties. Moreover, minimum prudential standards cannot be applied currently on a consolidated level. There is no aggregate that captures risks incurred by other group entities, e.g., large exposure limits. The rules for related party exposure need to be strengthened, allowing the CBR to presume interconnections, even if not formally established.

\section{Legal amendments are needed to provide adequate powers to CBR to perform} effective consolidated supervision. The amendments that would make such supervision effective include: (i) broadening the scope of supervision to include nonbank holding companies and mandate the disclosure of ultimate beneficiaries; and (ii) reporting compliance with prudential standards on a consolidated group basis. In addition, the CBR should be authorized to (a) inspect or mandate an external audit of a consolidated group; (b) require deduction from capital of excessive risk; (c) prohibit opaque and unsupervisable structures; and (d) provide means to insulate banks and banking groups from conglomeration risks. 
45. Coordination by supervisors in the financial sector (FFMS, CBR, and FSIS) also needs to be enhanced. Coordinated action would be facilitated by minimum levels of transparency, which would reduce the importance of nonpublic information in decision making and strengthen oversight and enforcement.

\section{The CBR has taken steps to improve cross-border cooperation in banking} supervision but is limited by legal restrictions. The banking law prohibits sharing of client information directly by supervisor while the Financial Intelligence Unit (FIU) can obtain client information, the supervisor cannot provide it unilaterally to the FIU. Home-host relationships are mostly focused on relations between the CBR and the home supervisors of foreign banks in Russia, as Russian banks have few establishments abroad. The CBR has concluded 22 memoranda of understanding with home supervisors of foreign banks, but cooperation, although in practice good, is limited by the legal restrictions on exchanging client information. The CBR has participated in several supervisory colleges and cooperates closely with a number of home regulators (the Netherlands, United Kingdom, and United States).

\section{Capital markets}

47. Since the last IOSCO assessment in 2003, the regulatory and legal framework for capital markets has been strengthened but the Federal Financial Markets Service (FFMS) requires additional enforcement authority. The securities law would be strengthened by defining and prohibiting insider trading and market manipulation. Gaps in the ability of the FFMS to obtain documents and records when conducting an investigation must be closed. The maximum fine for violations under the current law (approximately US $\$ 1,500)$ is too low to deter illegal conduct. The FFMS could also be authorized to require compensation for persons who were defrauded. Because important Russian companies are traded both in Russia and on foreign markets, the FFMS must have the ability to work closely with foreign regulators.

48. The FFMS should upgrade its capacity for market surveillance. Market surveillance is limited because securities can be simultaneously traded on MICEX, Russian Trading System Exchange (RTS), OTC, and in foreign markets. The FFMS would need online, real-time access to all markets, including foreign markets as well as analytical software to aggregate and monitor trading in a single security on all markets. Additionally, the triggers for exception reporting by RTS and MICEX could be reexamined to assess whether they are at the proper levels.

49. The FFMS's prudential regulations should be upgraded. Firms should be required to calculate working capital on a daily basis and to notify the FFMS when capital is approaching legal minimums. The FFMS requires the authority to appoint a temporary receiver or trustee to protect investor assets in the event of a failure by licensed market 
professionals. Regulations are also needed that create "suitability standards" for market professionals who make investment recommendations to retail investors.

\section{Public company disclosure has improved in recent years but additional}

improvements are necessary. Ownership disclosure by officers, directors, and controlling shareholders of public companies should be mandated in the law, and the requirement should make clear that it is beneficial rather than nominal ownership that must be disclosed. In addition, the FFMS should be authorized to instruct public companies to restate or correct false or misleading public disclosures.

\section{Insurance}

\section{Recent reform of the insurance supervision framework has strengthened the} sector but challenges remain. Key insurance supervisory practices were not incorporated in the law. These include (i) rules relating to the fit and proper status of owners, directors, and managers; (ii) the right to approve changes in ownership and control of an insurer; (iii) the ability of the supervisor to respond to immediate threats to an insurer without referring to the Ministry of Finance; (iv) adequate oversight of reinsurance arrangements; and (v) rules on the use of derivatives and consumer protection. Other challenges include strengthening the financial conditions of the sector with particular emphasis on asset quality. In addition, (i) asset risk is not adequately measured under the simplified EU solvency I formula used and (ii) the basis for educating and accrediting actuaries needs to be urgently established and promulgated. Current reinsurance per risk retention levels in Russia are probably excessive by international standards (although adequate on a per event basis) and reinsurer quality requirements could be strengthened. Further, capital requirements are still relatively modest compared to other large emerging market economies and less than EU requirements for direct insurance.

52. As professional and supervisory capacities are being built, insurers could, as an interim step, be rated on their ability to pay claims. Such ratings would provide consumers with some guidance on the insurer's financial strength in what is currently a very opaque sector. Regardless, the Financial Sector Insurance Service (FSIS) - the insurance industry supervisor - or an industry SRO should publish sufficient data to enable informed observers to analyze the financial strength, profitability, and efficiency of each insurer. ${ }^{15}$

53. A number of steps would enhance the oversight by FSIS. The institution could be granted powers to issue purely technical directives within the existing policy framework. It would then be able to respond quickly to an evolving financial environment. Another step is

\footnotetext{
${ }^{15}$ At a minimum, data should include gross premium, net premium and claims, expenses, net assets, and reserves/provisions.
} 
the development of an institutional strengthening plan covering staff recruitment, training, remuneration needs, data base and analytical platform, and management information system.

\section{B. Problem Bank Resolution and Safety Nets}

\section{Lender of last resort}

54. The CBR response to the August 2007 turmoil confirmed its ability to deal with systemic liquidity stress but further enhancements may be warranted. The CBR expanded the list of eligible Lombard collateral in September-November 2007. The CBR has considered expanding further its collateral base to deal with emergency situations including a broader set of eligible marketable securities. The acceptance by the CBR of nonmarketable assets from banks to collateralize credit should be combined with heightened supervisory oversight and clear triggers for bank intervention.

\section{Bank resolution framework}

55. The CBR has powers to require some early remedial action, change management, and intervene in a failed bank. In the past two years, measures to prevent insolvency have been applied in 125 banks by their shareholders and management as either required by the legislation or enforced by the CBR. In practice, however, the CBR has relied on violations of anti-money laundering legislation rather than soundness and safety grounds to close banks. Over the last two years, the CBR has withdrawn licenses from 115 banks and liquidation procedures have been completed for 106 .

56. The resolution framework would be strengthened if the CBR had the authority to intervene weak banks at an early stage. The CBR should have the authority to require shareholder recapitalization at an early stage of capital depletion. In the event the shareholders are unable to do so, the CBR would then have the option to intervene before bank capital falls below a predetermined level — such as 4 percent of risk weighted assetsand then sell parts or all of the bank to qualified purchasers. The overall enforcement regime would also be strengthened if economic sanctions could be applied to directors and managers. The CBR cannot impose such sanctions on directors and managers under the current banking law, and the responsibilities of the former in governing banks and banking groups are not clearly spelled out.

\section{Contingency planning is an essential aspect of bank supervision that should be} strengthened. Such plans would allow policymakers to focus on the most appropriate policy response rather than managing the details of the bank resolution process. Such plans should include:

- $\quad$ procedures to exchange real-time information among relevant CBR departments; 
- $\quad$ the CBR needs authority to require restructuring or resolution plans for illiquid but solvent banks; and

- $\quad$ the CBR should be authorized to conduct purchase and assumption transactions or sell the failed bank to viable third parties.

58. The deposit insurance system provides depositor protection in the event of a failure. The Deposit Insurance Agency (DIA) is a paybox and, as such, does not have an active role in the problem bank resolution framework. Coverage levels appear adequate at Rub 400,000 (US\$17,000) including a copayment of 10 percent copayment for amounts exceeding Rub 100,000. A review of the features of the deposit insurance system, particularly in light of recent experiences in other European countries, could be warranted, particularly with respect to coinsurance. Efforts could be enhanced to ensure that the extent of coverage and solvency of the system is fully recognized by depositors.

\section{Anti-Money Laundering and Combating the Financing of Terrorism ${ }^{16}$}

59. Minor shortcomings in the criminalization of money-laundering and terrorist financing were identified, reflecting the incomplete coverage of offenses and the lack of criminal liability for legal persons. The systems for confiscation of the proceeds of crime were judged effective but problems were identified in the regime for freezing terrorist assets including overreliance on the judicial system and issues with the procedures for delisting persons and unfreezing assets. The legal framework for cross-border declaration of currency should be better integrated into the law. The Financial Intelligence Unit performed effectively and only minor shortcomings were found in the work of other law enforcement authorities.

\section{All required financial institutions and certain nonfinancial institutions are fully} covered by the AML/CFT regime but weaknesses were found. Weaknesses existed in the customer due diligence framework, including lack of clarity concerning beneficial ownership requirements. Lawyers, notaries, and accountants are covered by a less strict regime considered incomplete and ineffectively implemented, and trust and company service providers are not covered. Loopholes that could permit criminal ownership of financial institutions have not been closed. The CBR's AML/CFT inspections were assessed positively, but some fault was found with legal limitations on the frequency of inspections and sanctioning power. AML/CFT supervision of other sectors was deemed ineffective.

\footnotetext{
${ }^{16}$ The following summary reflects the findings of the Financial Action Task Force (FATF) mutual evaluation mission which visited Russia in the period October and November, 2007. The mutual evaluation report was adopted by the FATF in June 2008. An AML/CFT ROSC will be prepared and circulated to the Executive Board for information following the expected adoption of the report in mid-July 2008 by the Eurasian Group and MONEYVAL - FATF-style regional bodies of which Russia is a member.
} 
While provisions for international cooperation appeared robust, inadequate statistics precluded an evaluation of their practical effectiveness.

\section{Market Infrastructure}

\section{Systemic liquidity management}

61. The CBR has effectively managed systemic liquidity but steps could be taken to further improve its effectiveness. The CBR monitors daily liquidity needs in the markets and projects liquidity needs. This system has proven robust in the difficult circumstances of market turmoil. Nevertheless, excess reserves held by banks remain significant. Steps to reduce the need for precautionary balances could include strengthening the payment system infrastructure. ${ }^{17}$ In addition, monthly tax collections result in strong intra-month volatility of the overnight interest rate. The shift to a quarterly payment schedule for VAT taxes may create significant liquidity pressures. The Ministry of Finance could be encouraged to introduce cash management systems that, in coordination with the CBR's liquidity management facilities, would smooth such fluctuations.

62. The Russian interbank market is thin and segmented. The large state-owned and large private banks hold most of the system's liquid assets and lend to some of the more illiquid, smaller banks. This redistribution of liquidity between the two tiers has largely taken place through the collateralized (repo) interbank market. However, not all of the needs of market participants are met. Interbank market constraints could be eased by improved governance and transparency, wider availability and distribution of the system's liquid assets, and improved laws and regulations for intervening and when liquidating banks. ${ }^{18}$

\section{Accounting and auditing}

\section{Progress has been made towards aligning Russian and international accounting} standards, but important differences remain. The accounting standards for credit institutions, in effect from January 1, 2008, are closely aligned with the IFRS. However, the overall 2004 strategy to align Russian Accounting Standards (RAS) with IFRS was delayed by an emphasis on complying with tax laws, and substantive differences between IFRS and RAS on (i) revenue recognition; (ii) consolidation; (iii) employee benefit and pension accounting; (iv) impairment testing; (v) the application of fair value measurement; and (vi) related-party disclosure requirements.

\footnotetext{
${ }^{17}$ Commercial banks' liquidity management is hampered by the late availability of funds, as most payments are settled by the CBR after 7:00 pm but the money market closes at 5:00 pm. CBR facilities can be accessed to deal with intraday funding gaps.

${ }^{18} \mathrm{MCM}$ technical assistance provided recommendations to improve the operation of the interbank market.
} 
64. In the banking sector, since 2004, the CBR requires all credit institutions to prepare supplementary IFRS financial statements but does not require that they be published. While the IFRS-based accounting standards were introduced in January 2008 publication of IFRS consolidated financial reporting will only be required when a law on consolidation is passed by the Duma.

\section{Capital markets infrastructure}

65. The capital markets infrastructure is fragmented and inefficient. The two markets, MICEX and Russian Trading System (RTS), have significant differences that raise costs and contribute to market fragmentation. MICEX listings are ruble-denominated and the market has a prepayment requirement. RTS listings are dollar-denominated and the market does not impose a prepayment requirement.

66. Secondary market trading in Russia is limited by high transaction costs, clearance and settlement risks, and the perception that investor rights are poorly protected. Operational costs are high because of multiple back-office procedures to accommodate different trading platforms and trade processing requirements. Operational risks increase with the complexity of the back-office functions. Many foreign investors have requirements that restrict their ability to invest in markets without a central depository that meets international standards.

67. Increased process automation is necessary to reduce risks stemming from the time-consuming, inefficient system for securities registration. At end-2006, there were 67 licensed securities registries; many require manually signed transfer forms to record transfer of ownership. Errors in these systems could prevent a purchaser from receiving a dividend, being able to vote a share, or reselling shares. The FFMS is attempting to simplify the system and introduce a new system for registry fees.

68. While MICEX and RTS own and operate their own clearance and settlement systems, neither entity has been legally designated a central counterparty. As a result, they cannot provide full legal protection and certainty to the clearance and settlement process. The stock exchanges are attempting to address this issue through the use of contractual agreements among member firms, but it is uncertain whether this planned approach will withstand legal challenge in the event of a market failure. 


\section{AnNeX-Observance of Financial Sector Standards and COdes- Summary Assessment of Compliance With the Basel Core Principles of EFFECTIVE BANKING SUPERVISION}

\section{Summary, Key Findings, and Recommendations}

69. Banking supervision has strengthened significantly since the $\mathbf{2 0 0 3}$ assessment, even when measured against the more complex and demanding revised Basel Core Principles (BCP). The overall system of supervision is of high quality, well resourced, and staff has a high level of professionalism. In Russia, banking supervision is exercised by the Central Bank of the Russian Federation (CBR), on the basis of the Statute of the Central Bank (Statute), the Law on the Central Bank (CBL) and the Law on Banks and Banking Activity (BL). The CBR makes intensive use of its 78 regional offices in the exercise of supervision.

70. Clear progress has been made in a number of areas. They include the practice of day-to-day supervision over institutions, including licensing, supervisory reporting, off-site and on-site work, as well as corporate governance and internal controls and AML/CFT. The introduction of new accounting standards for financial institutions, which are closely aligned with the IFRS, from January 1, 2008, can strengthen management information and disclosure. The intention to appoint specific staff as supervisory portfolio managers for individual banks ("curators") is welcomed and encouraged.

\section{There are some areas where further strengthening of supervision would be} beneficial for depositors, banks, and supervisors. Some initiatives are already under way. Systems for the assessment of the soundness of acquisitions by banks, and for assessing country transfer and repayment risk need to be developed. Tightening of the system for loan classification and provisioning would be useful, at a time when globally the need is felt for more robust capital and capital calculation. A critical challenge is to shift supervision from a compliance based to a more risk-based approach, based on best supervisory judgment. Legal amendments are needed to provide adequate powers to the CBR to perform effective consolidated supervision. Also, in order to maintain good working relationships with banks, there may be a need to look for ways to lower the regulatory and supervisory burden on banks and on CBR staff.

\section{Introduction and methodology of the assessment}

\section{An assessment of compliance with the revised Basel Core Principles (BCP),} adopted in October 2006, took place in coordination with the authorities. The assessment was conducted based on an extensive and high quality self-assessment prepared by the CBR, laws, regulations, a "sterilized" inspection report, and discussions with CBR staff from a variety of departments as well as commercial banks. The assessment was prepared by Michael Edwards (World Bank) and Jan Willem van der Vossen (IMF). The CBR's very cooperative and forthcoming stance greatly contributed to the work. 


\section{Institutional and macroeconomic setting and market structure_-overview}

73. Russia's economy has grown robustly in recent years with substantial balance of payments and fiscal surpluses and a large accumulation of international reserves. High oil prices, as well as improved macroeconomic management, have contributed significantly to Russia's favorable situation, which has attracted substantial interest from foreign investors, boosted domestic incomes, and spurred credit growth.

74. The financial system is bank dominated and has grown quickly. However, it is still smaller than many Western European countries. At end-2006 financial system assets relative to GDP stand at just under 60 percent, compared to over 300 percent in France, Germany, and Spain. Commercial banks account for over 90 percent of total financial assets.

\section{The banking sector of Russia comprises some 1,200 institutions, has adequate} profitability, but is fragmented, with a thin and segmented interbank market. Balance sheet total of credit institutions amounts to roughly Rub 20 trillion at end-2007, and the average risk weighted capital adequacy ratio stood at 15.5 percent. Profitability is adequate, with an ROA of 3.0 percent, and ROE of 22.7 percent. Liquidity covers around 73 percent of short term liabilities. Total NPLs amount to around 2.2 percent of total gross bank loans, whereas provisioning amounts to 3.4 percent of total gross loans.

\section{Preconditions for effective banking supervision}

76. Soundness and sustainability of macroeconomic policies. Economic growth is robust, with strong external and fiscal surpluses. International reserves are substantial, and the economy is well positioned to deal with macroeconomic shocks. However, growing demand pressures are raising inflationary concerns, and if oil prices stabilize or decrease, Russia's external and fiscal surpluses could be reversed.

77. Disclosure and transparency need further development. Notwithstanding a degree of convergence between Russian and international accounting standards, important differences remain on revenue recognition, consolidation, employee benefit and pension accounting, impairment testing, the application of fair value accounting, and related party transaction disclosure requirements. Although plans exist to enhance financial reporting in Russia, further measures are required. A proposal has been submitted on consolidation of accounts, and on mandatory use of IFRS by banks. This would also apply to listed companies, insurers, pension funds and other public companies, benefiting disclosure and transparency and improve the effectiveness of supervision and regulation. 


\section{Mechanisms for systemic protection or public safety net}

78. The CBR has powers to address liquidity stress and take early remedial action. Depositor protection is complemented by deposit insurance. The CBR's response to the financial sector turmoil has confirmed its ability to respond to the liquidity stresses in the system. The CBR has powers to require early remedial action, mandate change of management and intervene in a failed bank. Over the last two years, the CBR has closed over 100 banks. A system for early intervention as well as powers to take action against individual managers and directors, would enhance the CBR's powers, Since 2005, Russia has a Deposit Insurance Agency, which has improved the level of confidence of depositors in the system. Since its inception, the DIA has paid off insured deposits in 22 closures of small insured banks.

\section{Main findings}

\section{Objectives, independence, powers, transparency, and cooperation (CP 1)}

79. The objectives of banking supervision, the powers of the regulator, transparency and cooperation with other supervisory bodies, domestically and abroad, are fully or largely in line with the requirements of the BCP. The objectives are clearly defined in the law, and elaborated in a large number of regulations and other guidance material. Laws and regulations are updated as needed. The CBR is operationally autonomous, but subject to heavy oversight from the National Banking Council, which consists of Duma members, CBR, presidential, and government representatives. The CBR's supervisory work is adequately funded, and staff is adequate in numbers and of excellent quality. The CBR issues an Annual Report to the Duma, which contains an analysis of the situation of the Russian banking system, and an anonymous overview of enforcement actions against banks. A separate Banking Supervision Report is issued annually as are a monthly banking statistics bulletin and a weekly CBR bulletin, and the CBR operates a website. Although a considerable number of MoUs with foreign regulatory agencies are in place, a significant improvement of cooperation with other regulators could be achieved if the prohibition of the CBR to share, even confidentially, client information, could be lifted.

\section{Licensing and structure (CP 2-5)}

80. Bank licensing is generally well regulated Areas such as the range of activities permitted to a bank, the prohibition of use of the word "bank" by nonlicensed institutions, and the licensing criteria are well regulated. Nevertheless, strengthening is possible in fully assessing the suitability of owners and shareholders and using professional judgment. Prior permission for acquisitions by a bank is only required for domestic acquisitions. Foreign investments by Russian banks require prior approval by the CBR, when the bank becomes parent of a subsidiary abroad, or of a nonresident entity. Review by the CBR of acquisitions of shares in a bank takes place only above 20 percent. 


\section{Prudential regulations and requirements (CP 6-18)}

The CBR has issued an extensive range of prudential standards, covering all main risk areas. Capital adequacy, risk management, large exposures, related party exposures, market, liquidity and operational risk, interest rate risk and control and audit are largely in line with international standards. A regulation should be introduced to cover country risk and transfer risk. Loan classification and provisioning requires tightening. The current system leaves banks much discretion in classification of loans and setting provisioning percentages. In particular the range for setting provisions for loans in the categories doubtful and problem loans of 20 to 100 percent is too large. The current system does not provide a sufficiently clear view of individual banks' asset quality, hence of capital, could imply substantial overstatement of capital, and hinders meaningful cross bank monitoring.

\section{Methods of ongoing banking supervision (CP 19-21)}

81. The general approach to supervision in Russia combines both on-site and off-site work, based on detailed manuals. An extensive reporting framework is in place. The CBR assesses the risk profile of individual banks and banking groups, and analyzes general developments in the banking sector. Based on its analysis, the CBR sets priorities for its supervisory work. The CBR has an off-site tracking system for compliance with CBR orders and remedial actions. Much of the on-site work is performed by staff of the CBR's regional branches. The system for supervisory reporting is extensive, and requires that banks submit monthly statement and profit and loss accounts, capital calculations, provisions, composition of the group, and other materials.

\section{Accounting and disclosure (CP 22)}

82. Banks' consolidated financial statements shall be audited once per year by a licensed external auditor. The audit report shall express an opinion whether the statements present a true and fair view of the financial condition of the group or institution. Banks' mandatory published financial statements are prepared according to Russian accounting standards (RAS). From January 1, 2008, bank accounting standards were brought significantly closer to IFRS, including use of the accrual method. Separately from the legal requirement, the CBR requires banks to prepare accounts based on IFRS, and encourages publication.

\section{Corrective and remedial powers of supervisors (CP 23)}

83. The CBR has a wide range of remedial and intervention powers for banks not in compliance with legal or regulatory standards, or engaging in unsafe or unsound practices. The measures range from a simple communication to the bank, to cease and desist orders, temporary administration and license withdrawal. However, the CBR is unable to restrict the voting rights of shareholders, limit payments to shareholders and to directors and senior staff, and cannot directly sanction bank directors and officers. The CBR and the Ministry of Finance are jointly preparing amendments to the Banking Law and Central Bank law to address these aspects. 


\section{Consolidated and cross-border banking supervision (CP 24-25)}

84. In certain aspects, the CBR's rules on consolidated supervision do not meet internationally accepted approaches and the Basel requirements. The CBR and the Ministry of Finance are amending the law to strengthen the CBR's authority with regard to bank holding companies, including sanctions, clarification of the CBR's powers to take actions against banks for violations within the group, removing certain legal barriers against information exchange within groups, and the right of the CBR to request information from other domestic agencies.

\section{Home-host relationships are mostly focused on relations with home supervisors} of foreign banks in Russia, as Russian banks have few establishments abroad. Arrangements have been concluded with a significant number of foreign supervisory agencies, but cooperation, although in practice good, is limited by the legal restrictions on exchanging client information. The CBR has concluded 22 MOUs. The CBR has participated in a number of supervisory colleges and cooperates closely with a number of home regulators, such as the U.K., U.S., and the Netherlands. Foreign regulators have visited Moscow to perform inspections of subsidiaries of their banks.

Table 1. Summary Compliance with the Basel Core Principles-ROSC

\begin{tabular}{|c|c|}
\hline Core Principle & Comment \\
\hline \multicolumn{2}{|l|}{$\begin{array}{l}\text { 1. Objectives, autonomy, } \\
\text { powers, and resources }\end{array}$} \\
\hline 1.1 Objectives & $\begin{array}{l}\text { Publicly disclosed laws and regulations clearly set out the CBR's } \\
\text { supervisory responsibilities. }\end{array}$ \\
\hline 1.2 Independence & $\begin{array}{l}\text { The CBR exercises its functions independently of other federal bodies, } \\
\text { regional or local authorities; CBR staff can exercise their duties without } \\
\text { interference from the industry or political pressure. }\end{array}$ \\
\hline 1.3 Legal framework & The regulatory and supervisory functions of the CBR are based in law. \\
\hline 1.4 Enforcement powers & The CBR has an adequate range of remedial powers \\
\hline 1.5 Legal protection & CBR staff cannot be sued individually for the exercise of their duties. \\
\hline 1.6 Information sharing & $\begin{array}{l}\text { CBR exchanges information with other state agencies; the CBR has } \\
\text { concluded } 22 \text { publicly disclosed MOUs on information exchange with } \\
\text { foreign supervisory agencies. The Central Bank Law effectively bars the } \\
\text { exchange of client information with foreign authorities. }\end{array}$ \\
\hline 2. Permissible activities & $\begin{array}{l}\text { The law defines permitted activities. The use of the name "bank" is } \\
\text { prohibited to nonlicensed institutions. }\end{array}$ \\
\hline 3. Licensing criteria & $\begin{array}{l}\text { The CBR is submitting amendments to tighten the requirements for the } \\
\text { senior managers, Board members, and the founders (shareholders) of } \\
\text { credit institutions. Licensing criteria are broadly in line with good } \\
\text { practice. }\end{array}$ \\
\hline 4. Ownership & $\begin{array}{l}\text { The grounds of refusal of preliminary permission for the acquisition of } \\
\text { bank shares broadly correspond to international practice. The CBR } \\
\text { refuses permission if the acquirer is unsuitable according to the law. }\end{array}$ \\
\hline 5. Investment criteria & $\begin{array}{l}\text { Domestic acquisitions by Russian banks do not require prior permission } \\
\text { of the CBR. }\end{array}$ \\
\hline 6. Capital adequacy & The regulations on capital adequacy are in line with international good \\
\hline
\end{tabular}




\begin{tabular}{|c|c|}
\hline & practice. \\
\hline 7. Risk Management & $\begin{array}{l}\text { The CBR has issued numerous regulations which require that banks have } \\
\text { internal risk management processes, including credit risk. }\end{array}$ \\
\hline 8. Credit risk & $\begin{array}{l}\text { The CBR evaluates banks' credit policies, monitoring practices and how } \\
\text { violations reported and dealt with. }\end{array}$ \\
\hline $\begin{array}{l}\text { 9. Problem assets, } \\
\text { provisions and reserves }\end{array}$ & $\begin{array}{l}\text { The provisioning regulations are unusually flexible, in particular for } \\
\text { seriously impaired assets, and allow banks too much leeway, potentially } \\
\text { leading to underprovisioning and unclear statement of capital. }\end{array}$ \\
\hline 10. Large exposure limits & The CBR has defined large exposures and set limits. \\
\hline 11. Related party exposure & $\begin{array}{l}\text { The CBR has defined related party exposure and set limits. However, it } \\
\text { does not at this time have powers to require submission of related } \\
\text { enterprise records from entities above or beside the bank in the group } \\
\text { structure. }\end{array}$ \\
\hline $\begin{array}{l}\text { 12. Country and transfer } \\
\text { risk }\end{array}$ & $\begin{array}{l}\text { The CBR does not impose country risk limits or provisions, except for } \\
\text { operations with residents of offshore zones. The CBR is preparing } \\
\text { recommendations to banks on country risk. }\end{array}$ \\
\hline 13. Market risks & CBR has laid down rules for market risk based on Basel requirements. \\
\hline 14. Liquidity risk & The CBR has laid down adequate rules on liquidity risk. \\
\hline 15. Operational risk & $\begin{array}{l}\text { The CBR has issued recommendations on operational risk. It is } \\
\text { preparing recommendations for inspection of IT systems. }\end{array}$ \\
\hline 16. Interest rate risk & $\begin{array}{l}\text { The CBR has issued interest rate risk regulations, and has issued } \\
\text { additional recommendations on IRR in line with international practice. }\end{array}$ \\
\hline $\begin{array}{l}\text { 17. Internal control and } \\
\text { audit }\end{array}$ & The CBR has issued extensive internal control and audit rules. \\
\hline $\begin{array}{l}\text { 18. Abuse of financial } \\
\text { services }\end{array}$ & $\begin{array}{l}\text { The supervisors do not have the authority to directly share client } \\
\text { information with other agencies and regulators, at home or abroad, but } \\
\text { can share such information with the Financial Intelligence Unit. The } \\
\text { CBR aggressively closes banks that are involved in money laundering. }\end{array}$ \\
\hline 19. Supervisory approach & $\begin{array}{l}\text { The CBR analyzes numerous periodic reports on each bank's financial } \\
\text { condition and prudential requirements, and follow up through extensive } \\
\text { on-site work. }\end{array}$ \\
\hline 20. Supervisory techniques & $\begin{array}{l}\text { The CBR uses a combination of off-site and on-site work, and has a } \\
\text { strong on-site workforce, as well as elaborate manuals, although more } \\
\text { scope for professional judgment would further enhance the process. }\end{array}$ \\
\hline 21. Supervisory reporting & The CBR has built an extensive system of prudential reporting. \\
\hline $\begin{array}{l}\text { 22. Accounting and } \\
\text { disclosure }\end{array}$ & $\begin{array}{l}\text { As corporations, banks are required to issue annual statements compliant } \\
\text { with Russian accounting standards. The CBR additionally requires banks } \\
\text { to prepare IFRS statements and recommends banks to publish these. }\end{array}$ \\
\hline $\begin{array}{l}\text { 23. Corrective and remedial } \\
\text { powers }\end{array}$ & $\begin{array}{l}\text { The CBR disposes of an adequate range of remedial powers, including } \\
\text { license withdrawal. However, it cannot sanction individual bank } \\
\text { directors and officers (at nonintervened banks). }\end{array}$ \\
\hline $\begin{array}{l}\text { 24. Consolidated } \\
\text { supervision }\end{array}$ & $\begin{array}{l}\text { In order to obtain more complete data on the activities of a bank on a } \\
\text { consolidated basis, the CBR is working to improve the regulatory base of } \\
\text { consolidated regulation and the implementation of conservative methods } \\
\text { of consolidated risk assessment in regulatory practice. }\end{array}$ \\
\hline 25. Home-host relationships & $\begin{array}{l}22 \text { MOUs have been concluded. Parallel or separate inspections by } \\
\text { foreign supervisors can take place. The central bank law forbids } \\
\text { exchange of client information to other country authorities. }\end{array}$ \\
\hline
\end{tabular}




\section{Recommended Action Plan and Authorities' Response}

Table 2. Recommended Action Plan to Improve Compliance with Basel Core Principles

\begin{tabular}{|c|c|}
\hline Reference Principle & Recommended Action \\
\hline $\begin{array}{l}\text { 1.1 Responsibilities and } \\
\text { Objectives }\end{array}$ & $\begin{array}{l}\text { Implement action plans included in the Strategy for the Development of } \\
\text { the Banking Sector and the Guidelines for State Monetary Policy in } 2007 .\end{array}$ \\
\hline $\begin{array}{l}1.2 \text { Independence, accountability } \\
\text { and transparency }\end{array}$ & $\begin{array}{l}\text { Balanced by appropriate accountability structures, consider a higher level } \\
\text { of representation of the CBR in the National Banking Council, request } \\
\text { stronger political support for the CBR's work in the banking sector, and } \\
\text { provide an explicit legal basis for the CBR's role in financial stability. }\end{array}$ \\
\hline 1.3 Legal Framework & $\begin{array}{l}\text { Commence a project to streamline banking regulations, to make them more } \\
\text { accessible to banks and supervisors. }\end{array}$ \\
\hline 1.4 Legal Powers & $\begin{array}{l}\text { Continue work to introduce a stronger legal basis for the CBR's use of } \\
\text { professional judgment in its work, accompanied by appropriate } \\
\text { accountability. }\end{array}$ \\
\hline $\begin{array}{l}1.5 \text { Legal Protection of } \\
\text { Supervisors }\end{array}$ & $\begin{array}{l}\text { Prepare a written CBR guideline to confirm that the CBR will finance the } \\
\text { legal defense of individual officials, from the beginning of the procedure, } \\
\text { in advance, not just reimbursement after the fact. }\end{array}$ \\
\hline $\begin{array}{l}1.6,24 \text { and } 25 \text { Cross border } \\
\text { cooperation }\end{array}$ & $\begin{array}{l}\text { Remove unwarranted legal barriers against exchange of individual client } \\
\text { information. }\end{array}$ \\
\hline 3 Licensing criteria & $\begin{array}{l}\text { Strengthen vetting of senior managers, shareholders, and Board members, } \\
\text { allowing for the use of professional judgment by the supervisor, i.e., } \\
\text { lowering the vetting threshold to } 10 \text { percent of shares, versus the } \\
\text { current } 20 \text { percent. }\end{array}$ \\
\hline $\begin{array}{l}4 \text { Transfer of Significant } \\
\text { Ownership }\end{array}$ & $\begin{array}{l}\text { Lower threshold for the vetting of shareholders to } 10 \text { percent } \\
\text { from } 20 \text { percent. }\end{array}$ \\
\hline 5 Major acquisitions & $\begin{array}{l}\text { Introduce vetting of domestic acquisitions by domestic banks, not just } \\
\text { acquisitions abroad. }\end{array}$ \\
\hline 7 Risk management & $\begin{array}{l}\text { Continue to work on introduction of regulations on banks' risk } \\
\text { management, e.g., by strengthening requirements of the Banking Law with } \\
\text { regard to the functions and composition of the banks' Boards of Directors, } \\
\text { and amending the Central Bank Law to allow the CBR to issue regulations } \\
\text { on bank governance. }\end{array}$ \\
\hline $\begin{array}{l}9 \text { Problem assets, provisions and } \\
\text { reserves }\end{array}$ & $\begin{array}{l}\text { Tighten provisioning requirements to make them more precise, by limiting } \\
\text { the range of provisioning values per classification. This will also permit } \\
\text { more robust capital calculations. }\end{array}$ \\
\hline 11 Exposure to related parties & $\begin{array}{l}\text { Reinforce ability of CBR to obtain information on nonbank group entities, } \\
\text { including holdings and "sister" companies. Amend Article } 4 \text { of Banking } \\
\text { Law to broaden definition of related parties, Introduce } 25 \text { percent limit on } \\
\text { exposure to "groups of connected debtors." }\end{array}$ \\
\hline 12 Country and transfer risks & Introduce regulations on country and transfer risk. \\
\hline 14 Liquidity risk & $\begin{array}{l}\text { Continue work to introduce a new approach to liquidity supervision, and } \\
\text { issue new recommendations or regulations to banks, including that the } \\
\text { Board of a bank approve the liquidity strategy. }\end{array}$ \\
\hline 15 Operational risk & $\begin{array}{l}\text { Continue work to prepare methodological recommendations on IT and } \\
\text { technology risks. }\end{array}$ \\
\hline 20 Supervisory techniques & $\begin{array}{l}\text { Amend the Banking Law to permit follow-up inspections of a bank on the } \\
\text { same topic, with appropriate safeguards to prevent the supervisory burden. }\end{array}$ \\
\hline
\end{tabular}




\begin{tabular}{|c|c|}
\hline Reference Principle & Recommended Action \\
\hline 22 Accounting and auditing & $\begin{array}{l}\text { Implement the new accounting rules, which are more closely IFRS based. } \\
\text { Amend the Law on Auditing Activity and issue CBR recommendations on } \\
\text { audits of banks and consolidated groups. }\end{array}$ \\
\hline $\begin{array}{l}23 \text { Corrective and remedial } \\
\text { powers }\end{array}$ & Introduce sanctions against individual directors and officers of a bank. \\
\hline 24 Consolidated supervision & $\begin{array}{l}\text { Introduce broader powers with regard to bank holding companies, and } \\
\text { "sister" companies. Continue to improve the database on consolidated } \\
\text { groups. Continue to work with the Ministry of Finance to update the main } \\
\text { provisions of the rules on supervision on a consolidated basis. }\end{array}$ \\
\hline
\end{tabular}

\section{Authorities' response to the assessment}

\section{While broadly in agreement with the assessment, the authorities wish to state their difference of view with regard to the evaluation of two core principles (CPs 9 and 18).}

87. Regarding CP 9 on loan loss provisions, while recognizing that the practice of formation of loan loss provisions by banks is not always sufficiently conservative, and that the methodology and practice of supervision for formation of loan loss provisions require further improvement, the CBR does not agree with the assessment of CP 9 for the following reasons.

- $\quad$ The current system for formation of loan loss provisions was influenced by the following factors:

- need to develop risk-oriented supervision, including prudential requirements for banks with respect to credit risk assessment;

- $\quad$ need to select banks in the deposit insurance system; and

- $\quad$ need to implement the principles and approaches of International Financial Reporting Standards (hereinafter in the text - IFRS) in the bank accounting.

As a result, there was:

- generally positive result of the bank selection in the deposit insurance system, based on assessment of assets in accordance with Regulation No. 254-P; and

- $\quad$ more conservative loan loss provisions compared to the previously used procedure, and also compared to the results of formation of provisions within the framework of approaches envisioned by the IAS (IFRS) $39^{19}$;

\footnotetext{
19 Provisions created under the current requirements are approximately 10 percent higher than the provisions created in accordance with the previously applied approaches and in line with IAS (IFRS) 39.
} 
88. Accordingly, we believe that the current system for formation of loan loss provisions provides a more conservative approach than the previously used one and that this proceeds from the IFRS requirements. In light of the above and the 2002-03 assessment of CP 9, we consider the less favorable assessment unfounded because it characterizes the work that the CBR performed to improve loan loss provisioning as negative.

89. The assessment was based on the assessment that there are insufficiently conservative criteria for impaired quality of assets by the supervisor that is less than full compliance with Criterion 10 of CP $9 .{ }^{20}$ We think that a single criterion, even if one agrees that the assessment of compliance with this criterion, should not dominate overall compliance with CP 9, which is based on the assessment of compliance with the 11 other criteria. Thus, the CBR only agrees with the assessment of compliance with criterion 10 regarding the need to improve further the method for formation of loan loss provisions.

90. It seems that the assessment of the methods for determining loan loss provisions (Regulation No. 254-P) does not take into consideration a number of factors discussed, such as:

- $\quad$ practical aspect, i.e. conservative loan loss provisions as a result of applying the methodology (see above);

- $\quad$ approaches envisioned under the methodology were also discussed with the international experts, including a discussion within the framework of technical assistance program Banking Supervision and Accounting in 2003-2005 (TACIS). In fact, the aspects of methodology that the mission experts seem to consider nonconservative were substantially accepted by the TACIS experts;

- $\quad$ current approach allows use of professional judgment not only by banks, but also by the supervisor (CBR), which was not taken into consideration;

- $\quad$ current methodology effects a compromise between the IFRS and supervision approaches;

- the assessment is focused only on provisioning ranges for loan quality categories, while there are a number of regulations that narrow the ability of banks to use a subjective approach, including a conservative assessment of financial situation, quality of debt servicing, and other factors;

\footnotetext{
${ }^{20}$ EC 10: Laws, regulations, or the supervisor establish criteria for assets to be identified as impaired; e.g., loans are identified as impaired when there is reason to believe that all amounts due (including principal and interest) will not be collected in accordance with the contractual terms of the loan agreement.
} 
- $\quad$ assessment of the amount of provisions, which the assessors thought should be in the middle and upper levels of corresponding ranges, cannot be used for assessing the soundness of provisions formed by banks; and

- $\quad$ proposed "narrowing" of the range of provision allowance within one quality category would require either increasing the number of categories, which would make the boundaries between them more blurred, or it would lead to a mechanical (unsubstantiated) increase in requirements for the formation of provisions, which would be unjustified.

91. It should be pointed out that the CBR continuously works on improving the methodology and practice of formation of loan loss provisions, aimed at a gradual implementation of more conservative approaches, which was discussed with the assessors. At the same time, changes recommended by the assessors would mean moving away from the application of professional judgment by the supervising body and strengthening the position of those banks in lobbying for a return to formal supervision in general and to an actual softening in the approaches to formation of loss provisions in particular. Moreover, this would run contrary to the goals of the assessors and the CBR.

92. Comparison of indicators from the IMF database for Provisions for loan losses/total loans and Provisions to nonperforming loans for the countries that provide this information for publication with the values of equivalent indicators for Russia, which is provided in the text table below, does not allow a conclusion about inadequate provisioning in Russia, especially taking into account the stable situation and favorable outlook for development of the Russian economy.

93. Concerning CP 18 "Abuse of financial services" or sharing information with other regulators in Russia and abroad, it needs to be pointed out that, in respect of compliance with criterion $12^{21}$ of CP 18 , within the framework of Russian AML/CFT system there is a mechanism for an exchange of information on activities of credit organizations under surveillance (including data on operations of credit organizations and their clients) with foreign financial sector supervisory authorities.

94. Direct cooperation on information of the CBR with banking supervision authorities of foreign governments is accomplished through agreements on cooperation in the area of surveillance of activities of credit organizations (memoranda of understanding in the area of banking supervision), and absent these, on the basis of individual requests. In addition, the CBR can conduct cooperation on information, including information sharing on the abuse of

\footnotetext{
${ }^{21}$ The supervisor, directly or indirectly, cooperates with relevant domestic and foreign financial sector supervisory authorities or shares with them information related to suspected or actiual criminal activities, when this information is needed for supervisory purposes.
} 
financial services, whose disclosure falls under the banking confidentiality regime, through a mechanism of international cooperation of national agencies for financial surveillance.

95. It should be pointed out that, based on the results of the second round of mutual assessments of governments that are members of FATF, the Russian system of cooperation of supervisory and other authorized AML/CFT bodies was rated positively. The system also received a high grade in the report of the Select Committee of Experts for Evaluation of Anti-Money Laundering Measures of the Council of Europe (Moneyval) as a result of the second round of evaluation of the Russian Federation.

\section{Indicator Values for Provision for Loan Losses/Total Loans and Provisions to Nonperforming Loans for 2006 and 2007}

\begin{tabular}{|c|c|c|c|c|}
\hline & \multicolumn{2}{|c|}{$\begin{array}{l}\text { Provision for Loan } \\
\text { Losses/Total Loans }\end{array}$} & \multicolumn{2}{|c|}{$\begin{array}{l}\text { Provisions to Nonperforming } \\
\text { Loans } 1 /\end{array}$} \\
\hline & 2006 & 2007 & 2006 & 2007 \\
\hline & \multicolumn{4}{|c|}{ (percent) } \\
\hline Russia & 4.1 & 3.9 & 81.8 & 83.7 \\
\hline Ireland & 0.4 & $\ldots$ & $\ldots$ & $\ldots$ \\
\hline Dominican Republic & 2.4 & 2.2 & $\ldots$ & $\ldots$ \\
\hline Georgia & 1.7 & 1.8 & $\ldots$ & $\ldots$ \\
\hline Philippines & $\ldots$ & $\ldots$ & 75.0 & 74.8 \\
\hline Armenia & $\ldots$ & $\ldots$ & 64.3 & 66.6 \\
\hline Canada & $\ldots$ & $\ldots$ & 55.3 & 47.8 \\
\hline Croatia & $\cdots$ & $\cdots$ & 61.5 & 58.9 \\
\hline Tajikistan & $\cdots$ & $\cdots$ & 24.7 & $\cdots$ \\
\hline Romania & $\ldots$ & $\cdots$ & 32.0 & $\cdots$ \\
\hline Portugal & $\cdots$ & $\cdots$ & 80.0 & $\cdots$ \\
\hline Peru & $\cdots$ & $\cdots$ & 251.4 & 246.5 \\
\hline
\end{tabular}

1/ Provided indicator values for Provisions to nonperforming loans were calculated based on the data on provisions formed for overdue loans. For the calculation of indicator of total amount of provisions the indicator value was 343 for 2006 and 293.4 for 2007. 


\section{Appendix I. Stress Testing Methodology And Results}

\section{Methodology}

96. The CBR has made substantial progress since the 2003 FSAP to strengthen its work on financial stability, but new challenges are emerging with the rapid growth of the financial system. The CBR publishes Banking Supervision and Financial Stability Reports, has increased the amount of information provided on its website, and carries out vulnerability analysis, including analysis of trends, cluster analysis, and annual stress testing. CBR has also participated in the IMF pilot on FSIs. However, as the sophistication and openness of the financial system increases, the CBR needs to implement more advanced tools for analysis (especially for credit, liquidity, and funding risks). Further strengthening the financial stability analysis capabilities of the CBR will be needed to meet the new challenges, including better coordination among CBR departments, streamlining bank reporting forms, and more frequent engagement with banks on stress testing. ${ }^{22}$

\section{Top down stress tests were based on the CBR model with the size of shocks} agreed between the FSAP team and the authorities. Stress testing focused on the single factor shocks. A macroeconomic scenario was discussed, but left for further improvement due to data limitations and lack of capacity in the CBR to link the macroeconomic variables and risk factors relevant for stress testing. The existing CBR model covers most the key areas of credit, liquidity and market risks; its results are presented on an annual basis in the Bank Supervision Report. The stress tests were based on end-2006 individual bank prudential reports.

98. The following two approaches were taken to assess the sensitivity to credit risk: (a) an increase in provisioning to the maximum of the recommended range per risk category; ${ }^{23}$ and (b) for the corporate portfolio, an increase in loans with provisions over 50 percent or asset classification categories IV and V to 13.7 percent (or 1.65 standard deviations using data from 1998 to 2006); and doubling of NPLs for the household portfolio. This leads to an increase in categories IV and V to 8 percent of assets. Both scenarios assumed a 50 percent haircut on collateral. In order to assess credit concentration risk, ratios of the largest five borrowers by bank were also calculated.

\footnotetext{
${ }^{22}$ Currently, the CBR carries out an annual survey on stress testing and publishes guidelines on its website.

${ }^{23} \mathrm{Up}$ to 1 percent for category I assets; 10 percent for category II assets (middle of the recommended range of 1-20 percent more in line with international practice); 50 percent for category III assets; and 100 percent for categories IV and V.
} 


\section{Given model limitations, liquidity risk was assessed only on depositor}

withdrawal. In order to asses liquidity risk, an assumption was made based on historical experience on the reduction of retail and current corporate deposits by 30 percent and a withdrawal of corporate time deposits by 5 percent. In addition, a 5 percent haircut on highly liquid assets and 20 percent haircut on liquid assets were assumed. Two scenarios were considered, one with the access to the interbank market at the rates higher by 1,000 basis points, and another without access to the interbank market. Funding concentration risk was assessed by analyzing the share of top five creditors as a percent of total liabilities. Gap analysis on effective maturities was not carried out as the authorities do not collect the necessary data. The authorities are beginning to analyze funding risk for banks accessing domestic and international capital markets, but the approach is not yet integrated into stress testing. Results are presented as a loss in percent of bank capital due to haircuts and as a change in liquidity ratios by bank group.

100. In addition, contagion was analyzed where a bank that lost over 25 percent of capital under a combined shock of credit, market, and liquidity risks is assumed to affect the rest of the banking system directly via its counterparties in the interbank market as well as indirectly if one if its counterparties experiences liquidity difficulties as a result and propagates the shock.

101. Finally, to assess market risks, devaluation/revaluation of 15 percent, ${ }^{24}$ a drop of 30 percent in stock market, and a price drop of 20 percent on all debt instruments. The shocks were calibrated using historical data as well as expert judgment.

102. Interest rate risk at different maturities on the trading book and interest rate on the banking book were not assessed as the authorities do not collect the necessary data.

\section{To complement the top down stress tests, bottom up stress tests were conducted}

by five large banks. Stress tests focused on sensitivity analysis of the key risks: credit, liquidity, and market risks (foreign exchange, interest rate, basis, and equity risks).This exercise was the first time the authorities engaged with banks to provide results on stress testing and the CBR plans to continue direct cooperation with banks on stress testing methodologies.

\section{Key results}

104. Credit risk is the main concern for banks. The main driver is credit risk (Figure 1). Under the stress shock where loan categories IV and V are increased to 13.7 percent based on historical experience the banking system would lose over 50 percent of capital. About 200 banks, accounting for over half of banking system assets, would lose over

\footnotetext{
${ }^{24}$ Direct effect only; not including indirect credit risk due to unhedged borrowers.
} 
50 percent of capital. The most vulnerable group is state banks ${ }^{25}$ - their capital adequacy would fall from a group-weighted average of 12.7 percent to 3.2 percent. This fall was partially mitigated by the IPOs by two state banks in early 2007. Based on mid-2007 data that includes the effect of these IPOs, average capital adequacy of state banks would drop from about 20 percent per shock to slightly above 10 percent. The second most vulnerable group is large private banks. Credit risk concentration is also significant, where top five borrowers by bank account for more than 50 percent of bank capital in 84 percent of banks accounting for 90.6 percent of bank assets, which under Pillar II of Basel II would have solvency effects.

Figure 1. Credit Risk Stress Tests, end-2006
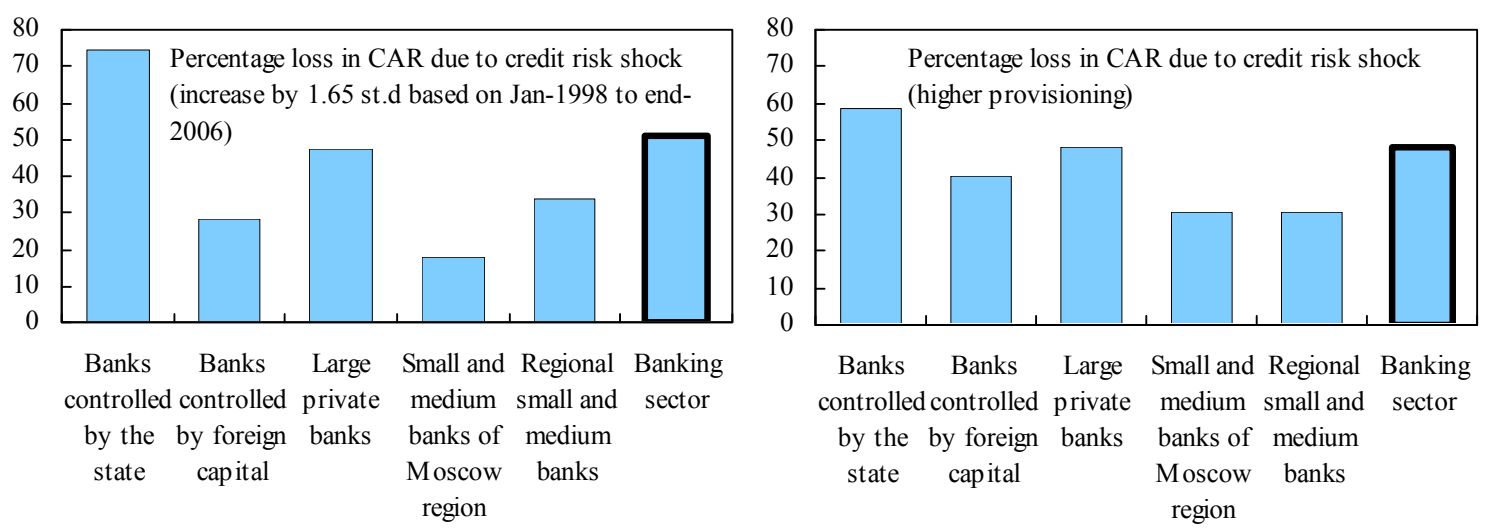

Source: CBR and IMF staff calculations.

105. Full provisioning to the maximum level for each category and mid-level for category II would reduce a system wide capital by 48 percent, the state banks being most vulnerable with 59 percent of capital loss, followed by the large private banks with 48 percent. Overall, 337 banks, accounting for about 69 percent of banking system assets, would lose over 50 percent of capital. As a result the system would become undercapitalized, with state banks well below the minimum capital adequacy requirement (not taking account of the 2007 IPOs discussed above).

\section{Exposure to depositor-induced liquidity risk, while less threatening on a} system-wide, is considerable for some subgroups of banks. Medium and small banks are sensitive to the funding concentration risk; top five creditors often account for more than 200 percent of their capital. A "flight to quality" shock would be devastating for this subgroup. By design, the state banks would incur the largest absolute loss of liquidity as they have the highest share of deposits in funding, but the high share of liquid assets mutes the

\footnotetext{
${ }^{25}$ The stress tests do not take into consideration the likelihood of government support.
} 
impact on overall liquidity. As a result, the reduction in capital of this group would be 9.3 percent, but the overall liquidity would remain high.

107. In the scenario with the interbank market domino effect, the most exposed were banks controlled by foreign capital (about 18 percent of capital, but mitigated by possible parent support) and most importantly large private banks (about 16 percent of bank capital).

108. A combined market risk stress test for the system as a whole would result in a 6 percent loss of bank capital. ${ }^{26}$ While no bank group becomes undercapitalized, a number of individual institutions would lose up 100 percent of their capital. The most exposed appear to be foreign and large private banks. Across bank categories most of the shock came from the discount of bond portfolios. The impact of direct currency risk was negligible (less than 1 percent of capital on both devaluation and revaluation) and stock market risk was limited at 2 percent of capital.

109. Bottom-up stress tests were based on five large banks representing 41 percent of banking system assets (three state-controlled and two private), the results broadly support top-down stress test results; they also highlight important differences between banks and risks that cannot be identified via top-down. Bottom-up stress test confirmed that credit risk is the key risk to the system, that credit concentration remains important (with one bank having top five credit exposures at about 100 percent of its capital), and that exposure to market risk varies dramatically from bank to bank (with one bank losing about 30 percent of its capital compared to about 8 percent for the group average). The shocks for market risk included in the bottom-up exercise were somewhat larger than the top-down shocks, but the results clearly demonstrate the range of different exposures. Interest rate risk on the balance sheet appears to be growing in importance and warrants supervisory attention (for example some banks reported a loss of up to 30 percent of capital for a parallel upward shift of 500 basis points).

\section{Main methodological recommendations}

\section{There is scope to improve the stress testing methodology in all risk areas:}

- In the area of credit risk the assumptions behind the shocks should be strengthened, including through detailed analysis of the potentially vulnerable loans still in categories I-III (for example restructured loans) and eventually linking risk factors to macroeconomic scenarios. In addition, an early start in the collection and implementation of credit risk VAR models for supervisory analysis would place the CBR in a better position for Basel II implementation in the long run.

\footnotetext{
${ }^{26}$ Not all securities are included in the stress test resulting in somewhat understated figures; the shock covered only the trading portfolio.
} 
- In terms of liquidity risk the CBR should carry out gap analysis on effective maturities incorporating all assets and liabilities, so as to effectively incorporate not only deposits, but also wholesale (domestic and foreign) funding sources of risk and concentration risk. Market risk stress testing would be significantly strengthened by analysis at the financial group level.

- Regarding bottom-up stress testing, further discussion and cooperation is needed between the CBR and individual banks on methodology, plausibility of underlying shocks, and eventually stress test results. This would be particularly important for liquidity and market risk where banks posses more timely and accurate information. In the area of liquidity risk, stress test results could be discussed together with banks' contingency plans. Over time, as the distinction between the banking and trading book is increasingly blurred, tests on market risk need to take it into account.

111. Further progress is needed on the links between macroeconomic variables and risk factors used in stress testing. The CBR has begun work in this area and further work is needed to establish the impact of macroeconomic variables on risk factors in stress tests, so the effects of macroeconomic scenarios on the financial sector can be analyzed through stress testing. 


\section{APPENDIX II. MACROECONOMIC AND FINANCIAL SECTOR INDICATORS}

Table 1. Selected Macroeconomic Indicators

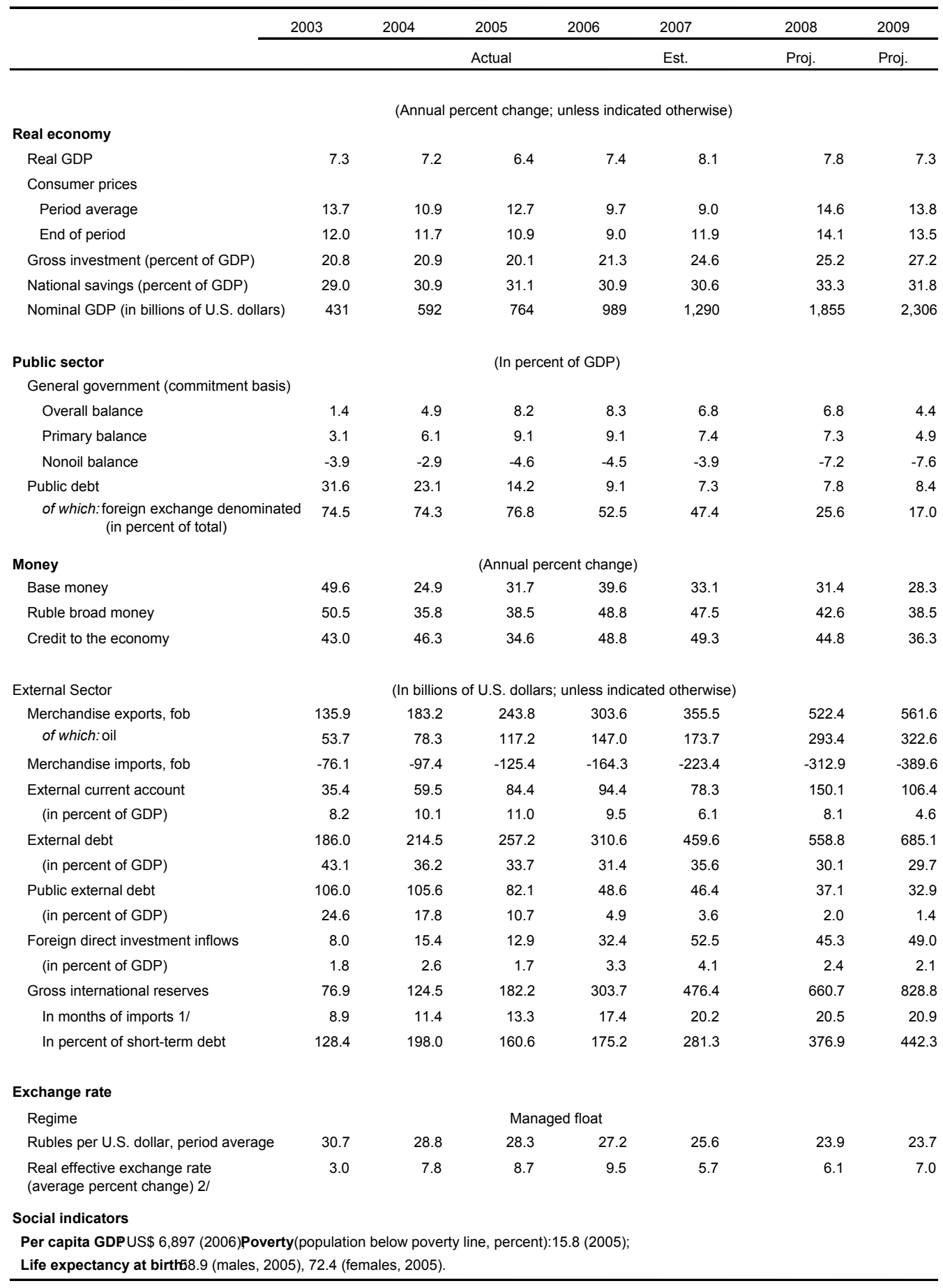

Source: Russian authorities; World Development Indicators 2006; and Fund staff estimates (as of June 2008 for latest projections).

$1 /$ In months of imports of goods and nonfactor services.

2/ Based on CPI. 
Table 2. Financial System Structure 1/

\begin{tabular}{|c|c|c|c|c|c|c|c|c|c|}
\hline & \multicolumn{3}{|c|}{2004} & \multicolumn{3}{|c|}{2006} & \multicolumn{3}{|c|}{2007} \\
\hline & $\begin{array}{l}\text { Assets } \\
\text { (Rub bn) }\end{array}$ & $\begin{array}{c}\text { Percent of } \\
\text { Total } \\
\text { Assets }\end{array}$ & Number & $\begin{array}{l}\text { Assets } \\
\text { (Rub bn) }\end{array}$ & $\begin{array}{c}\text { Percent of } \\
\text { Total } \\
\text { Assets }\end{array}$ & Number & $\begin{array}{l}\text { Assets } \\
\text { (Rub bn) }\end{array}$ & $\begin{array}{c}\text { Percent of } \\
\text { Total } \\
\text { Assets }\end{array}$ & Number \\
\hline Credit institutions & $7,136.9$ & 89.9 & 1,299 & $14,045.6$ & 90.1 & 1,189 & $20,241.1$ & $\ldots$ & 1,136 \\
\hline State-owned banks & $2,719.3$ & 34.3 & 21 & $5,306.6$ & 34.0 & 31 & $7,936.4$ & $\ldots$ & 24 \\
\hline Private banks & $4,377.1$ & 55.1 & 1,228 & $8,651.5$ & 55.5 & 1,112 & $12,209.6$ & $\ldots$ & 1,068 \\
\hline Domestic & $3,838.2$ & 48.4 & 1,187 & $6,954.1$ & 44.6 & 1,048 & $8,727.2$ & $\ldots$ & 983 \\
\hline Foreign $2 /$ & 538.9 & 6.8 & 41 & $1,697.4$ & 10.9 & 64 & $3,482.3$ & $\ldots$ & 85 \\
\hline Nonbank credit institutions & 40.4 & 0.5 & 50 & 87.5 & 0.6 & 46 & 95.0 & $\ldots$ & 44 \\
\hline Nonbank financial institutions & 800.0 & 10.1 & $\ldots$ & $1,549.3$ & 9.9 & $\ldots$ & $\ldots$ & $\ldots$ & $\ldots$ \\
\hline Unit investment funds (PIF) & 108.9 & 1.4 & $\ldots$ & 420.5 & 2.7 & 641 & $\ldots$ & $\ldots$ & $\ldots$ \\
\hline General bank management funds (OFBU) & 3.6 & 0.0 & $\ldots$ & 16.8 & 0.1 & 138 & $\ldots$ & $\ldots$ & $\ldots$ \\
\hline Private pension funds & 215.8 & 2.7 & $\ldots$ & 509.9 & 3.3 & $\ldots$ & $\ldots$ & $\ldots$ & $\ldots$ \\
\hline Insurance companies (premiums) & 471.6 & 5.9 & $\ldots$ & 602.1 & 3.9 & 918 & $\ldots$ & $\ldots$ & $\ldots$ \\
\hline Total & $7,936.9$ & 100.0 & $\ldots$ & $15,594.9$ & 100.0 & $\ldots$ & $\ldots$ & $\ldots$ & $\ldots$ \\
\hline
\end{tabular}

Source: Central Bank of Russia, Rosstat, Federal Insurance Supervision Service (FSSN), National Managers League, Federal Financial Markets Service, Cbonds, Tsentr Razvitiya (Center for Development).

1/ Excludes leasing companies.

2/ Majority foreign-owned. 
Table 3. Financial Soundness Indicators

\begin{tabular}{|c|c|c|c|c|c|c|c|}
\hline & 2002 & 2003 & 2004 & 2005 & 2006 & 2007 & $\begin{array}{c}\text { March } \\
2008\end{array}$ \\
\hline \multicolumn{8}{|l|}{ Capital adequacy } \\
\hline Regulatory capital to risk-weighted assets & 19.1 & 19.1 & 17.0 & 16.0 & 14.9 & 15.5 & 15.3 \\
\hline Capital to assets & 14.0 & 14.6 & 13.3 & 12.7 & 12.1 & 13.2 & 13.4 \\
\hline \multicolumn{8}{|l|}{ Asset quality } \\
\hline NPLs (cat. IV-V) to total gross loans $1 /$ & 5.6 & 5.0 & 3.8 & 3.2 & 2.6 & 2.2 & 2.1 \\
\hline NPLs (cat. III-V) to total gross loans & & & 13.6 & 12.3 & 10.8 & $\cdots$ & $\ldots$ \\
\hline Loan loss reserves to total gross loans & 6.3 & 5.9 & 5.3 & 5.0 & 4.1 & 3.4 & 3.3 \\
\hline Large exposures to capital $2 /$ & 228.6 & 241.0 & 242.8 & 239.8 & 240.6 & 211.9 & 211.2 \\
\hline \multicolumn{8}{|l|}{ Sectoral distribution of loans to total loans } \\
\hline Industry, of which & 36.7 & 33.3 & 28.0 & $\cdots$ & $\cdots$ & $\cdots$ & $\ldots$ \\
\hline Manufacturing & $\ldots$ & $\ldots$ & $\ldots$ & 16.3 & 14.6 & 13.5 & 13.8 \\
\hline Extraction & $\ldots$ & $\ldots$ & $\ldots$ & 3.5 & 3.9 & 3.1 & 2.7 \\
\hline Utilities & $\ldots$ & $\ldots$ & $\ldots$ & 2.3 & 2.0 & 1.7 & 1.7 \\
\hline Agriculture 4/ & 2.2 & 2.4 & 2.7 & 3.0 & 3.6 & 3.8 & 3.8 \\
\hline Construction & 4.4 & 4.4 & 4.5 & 4.6 & 4.9 & 6.0 & 6.1 \\
\hline Trade and pubic dining $5 /$ & 21.6 & 20.6 & 18.8 & 23.9 & 19.6 & 18.0 & 18.3 \\
\hline Transport and communication & 4.6 & 5.1 & 4.8 & 4.0 & 3.7 & 3.7 & 3.7 \\
\hline Others & 22.4 & 22.7 & 24.9 & 22.8 & 21.3 & 23.3 & 23.0 \\
\hline Individuals & 8.0 & 11.5 & 16.2 & 19.6 & 23.9 & 24.8 & 24.7 \\
\hline Of which mortgages & -- & -- & 0.5 & 1.0 & 3.0 & 5.1 & 5.5 \\
\hline \multicolumn{8}{|l|}{ Profitability } \\
\hline Return on assets & 2.6 & 2.6 & 2.9 & 3.2 & 3.2 & 3.0 & 2.9 \\
\hline Return on equity & 18.0 & 17.8 & 20.3 & 24.2 & 26.3 & 22.7 & 21.1 \\
\hline \multicolumn{8}{|l|}{ Liquidity } \\
\hline Liquid assets to total assets & 39.1 & 36.1 & 30.3 & 27.3 & 26.7 & 24.7 & 23.9 \\
\hline Liquid assets to short-term liabilities & 90.6 & 90.4 & 78.0 & 73.8 & 76.8 & 72.9 & 68.7 \\
\hline \multicolumn{8}{|l|}{ Market risk } \\
\hline Net open position in FX to capital & 0.0 & -0.2 & 0.6 & -0.8 & .06 & 2.2 & 2.1 \\
\hline \multicolumn{8}{|l|}{ Risk weighted exposure: } \\
\hline FX risk to capital & 18.5 & 8.4 & 5.8 & 5.8 & 5.3 & 3.6 & 3.5 \\
\hline Interest rate risk to capital & 6.9 & 9.9 & 13.3 & 13.3 & 19.3 & 24.3 & 26.8 \\
\hline Equity position risk to capital & 11.7 & 12.4 & 12.6 & 14.4 & 20.4 & 10.8 & 10.4 \\
\hline \multicolumn{8}{|l|}{ Other } \\
\hline Foreign exchange loans to total loans & 38.5 & 34.8 & 29.9 & 31.5 & 28.8 & 26.6 & 26.6 \\
\hline Foreign exchange deposits to total deposits $3 /$ & 43.8 & 33.9 & 31.2 & 28.7 & 20.4 & 17.0 & 23.2 \\
\hline
\end{tabular}

Source: Central Bank of Russia.

1/ 2002-03 data for categories III and IV, the definition used in that period.

2/ Calculated as the amount of large credit risk to capital.

3/ The 2008 data include certificates of deposit and savings certificates.

4/ Since 2005 data on agriculture are presented as agriculture, fishing, and forestry.

5/ Since 2005 data on trade and public dining are presented as wholesale and retail trade; repair of motor vehicles and motorcycles. 
Table 4. Summary Balance Sheet of the Banking System

(In billions of rubles unless stated otherwise)

\begin{tabular}{|c|c|c|c|c|c|c|c|}
\hline & & & & & & & March \\
\hline & 2002 & 2003 & 2004 & 2005 & 2006 & 2007 & 2008 \\
\hline Assets & $4,145.3$ & $5,600.7$ & $7,136.9$ & $9,750.3$ & $14,045.6$ & $20,241.1$ & $21,323.4$ \\
\hline Highly liquid assets & 808.8 & $1,102.1$ & $1,119.6$ & $1,205.1$ & $1,722.3$ & $2,209.7$ & $1,810.9$ \\
\hline Cash & 91.2 & 137.9 & 196.3 & 263.4 & 368.5 & 501.7 & 412.9 \\
\hline Accounts at CBR & 416.8 & 658.6 & 695.5 & 684.1 & 955.6 & $1,294.7$ & $1,056.8$ \\
\hline Correspondent accounts at banks & 300.9 & 305.6 & 227.8 & 257.5 & 398.2 & 413.3 & 341.2 \\
\hline Securities & 779.9 & $1,002.2$ & $1,086.9$ & $1,539.4$ & $1,961.4$ & $2,554.7$ & $2,252.5$ \\
\hline Government bonds 1/ & 412.8 & 447.0 & 435.6 & 492.0 & 537.2 & 580.3 & $1,563.9$ \\
\hline Corporate bonds & 89.8 & 178.1 & 317.0 & 544.5 & 803.9 & $1,093.7$ & $\ldots$ \\
\hline Equities & 68.7 & 115.8 & 140.9 & 292.8 & 391.0 & 629.6 & 430.1 \\
\hline Discounted bills of exchange & 200.8 & 261.3 & 193.4 & 210.1 & 229.2 & 251.1 & 258.5 \\
\hline Loans & $2,148.8$ & $3,048.0$ & $4,463.8$ & $6,371.1$ & $9,440.5$ & $14,260.1$ & $16,110.9$ \\
\hline Of which household loans & 141.2 & 298.4 & 616.5 & $1,174.9$ & $2,059.5$ & $3,234.6$ & $3,190.6$ \\
\hline corporate loans & $1,654.0$ & $2,385.0$ & $3,268.7$ & $4,274.8$ & $5,966.2$ & $9,046.2$ & $10,253.4$ \\
\hline interbank loans & 291.4 & 263.7 & 425.8 & 668.0 & $1,035.6$ & $1,418.1$ & $1,921.7$ \\
\hline Other assets & 407.7 & 448.5 & 466.6 & 634.7 & 921.4 & $1,216.6$ & $1,149.2$ \\
\hline Liabilities & $3,492.8$ & $4,766.4$ & $6,130.7$ & $8,430.1$ & $12,262.6$ & $17,431.9$ & $18,377.3$ \\
\hline Customer deposits & $2,194.5$ & 2,999.6 & $4,151.5$ & $5,818.9$ & $8,467.3$ & $12,053.1$ & $12,896.2$ \\
\hline Of which deposits of individuals & $1,060.7$ & $1,558.5$ & $2,026.7$ & $2,817.1$ & $3,881.8$ & $5,263.8$ & $5,313.6$ \\
\hline corporate deposits & 276.7 & 312.5 & 564.0 & 936.4 & $1,543.5$ & $2,584.7$ & $3,611.7$ \\
\hline Dues to banks & 315.4 & 525.3 & 737.1 & $1,086.4$ & $1,730.5$ & $2,807.4$ & $2,999.2$ \\
\hline Securities issued & 450.6 & 634.5 & 644.2 & 749.2 & $1,018.1$ & $1,176.1$ & $1,126.1$ \\
\hline Other liabilities & 532.3 & 606.9 & 597.9 & 775.6 & $1,046.6$ & $1,395.3$ & $1,355.8$ \\
\hline Capital and reserves & 652.5 & 834.3 & $1,006.1$ & $1,320.2$ & $1,783.0$ & $2,809.2$ & $2,946.1$ \\
\hline
\end{tabular}

Source: Central Bank of Russia.

1/ Data for March 2008 includes government and corporate bonds 
Table 5. Insurance Penetration and Density in Selected Markets, 2006

\begin{tabular}{lrrrr}
\hline & & $\begin{array}{c}\text { Insurance } \\
\text { Penetration } \\
\text { (Premium }\end{array}$ & $\begin{array}{c}\text { Insurance } \\
\text { Density } \\
\text { (Premium per } \\
\text { capita, USD) }\end{array}$ & $\begin{array}{c}\text { Population } \\
\text { (in millions) }\end{array}$ \\
\hline Russia & $\begin{array}{c}\text { Premium Volume } \\
\text { (in USD million) }\end{array}$ & GDP) & 150.9 & 142.5 \\
Brazil & $\mathbf{2 1 , 5 0 4}$ & $\mathbf{2 . 3}$ & 160.9 & 188.9 \\
Czech Republic & 30,390 & 2.8 & 519.6 & 10.2 \\
India & 5,304 & 3.8 & 38.4 & $1,119.5$ \\
Kazakhstan & 43,032 & 4.8 & 42.3 & 14.8 \\
Poland & 627 & 3.9 & 310.3 & 38.5 \\
Ukraine & 11,947 & 2.8 & 59.6 & 46.0 \\
G-7 average & 2,739 & 10.1 & $3,799.1$ & 128.2 \\
\hline
\end{tabular}

Source: Sigma Swiss Re.

Table 6. Gross Insurance Premiums

\begin{tabular}{|c|c|c|c|c|c|}
\hline & \multirow{2}{*}{$\frac{2004}{\text { (USD million) }}$} & \multicolumn{2}{|c|}{2005} & \multicolumn{2}{|c|}{2006} \\
\hline & & (USD million) & $\begin{array}{l}\text { Percent } \\
\text { Change }\end{array}$ & (USD million) & $\begin{array}{l}\text { Percent } \\
\text { Change }\end{array}$ \\
\hline Life & 3,549 & 896 & -75 & 586 & -35 \\
\hline $\begin{array}{l}\text { Accident and } \\
\text { private health }\end{array}$ & 1,837 & 2,260 & 23 & 2,813 & 24 \\
\hline Property $1 /$ & 5,316 & 6,558 & 23 & 8,349 & 27 \\
\hline Liability & 424 & 574 & 35 & 601 & 5 \\
\hline MTPL & 1,708 & 1,899 & 11 & 2,341 & 23 \\
\hline Total & 12,843 & 12,187 & -5 & 14,690 & 21 \\
\hline
\end{tabular}

Source: IMF.

1/ Property is the major source of financial scheme insurance. 


\section{APPENDIX III. IMPLEMENTATION OF RECOMMENDATIONS FROM THE 2003 FSAP}

The Russian authorities have adopted a series of measures aimed at addressing some of the most pressing issues raised by the 2003 FSAP.

\section{BANKING SYSTEM}

\section{Tighten the definition of capital and transparency of ownership structures.}

- $\quad$ Beginning early 2003, the Bank of Russia required its regional branch offices to evaluate the economic sources of capital and subordinated debt. When risks appear excessive, the Bank of Russia can require (i) a reduction in authorized capital; (ii) introduction of new investors, or (iii) creation of reserves against possible losses.

- With the introduction of the Deposit Insurance Law, the Bank of Russia strengthened its ability to monitor the ownership structure of commercial banks The Law establishes requirements for participation in the deposit insurance system by banks that have a Bank of Russia permit. Requirements for participation include (i) the bank's accounting and reporting statements are found to be reliable by the Bank of Russia; (ii) the bank must meet prudential requirements established by the Bank of Russia; and (iii) the bank's financial viability is found by the Bank of Russia to be adequate.

- In accordance with the Law on Deposit Insurance, the Bank of Russia is required to evaluate the transparency of a bank's ownership structure and the adequacy of information about persons who have a direct or indirect influence on decisions made by a bank's management bodies. The Bank of Russia must also evaluate the importance of offshore banks. The Bank of Russia also performs a similar evaluation when reviewing petitions from banks to expand their banking activity

- $\quad$ The Bank of Russia monitors the ownership structure if shareholder shares are modified. The Bank of Russia must approve the acquisition of more than 20 percent of the stock of a commercial banks lending by a single legal entity or individual or group of legal entities.

\section{Address the uneven playing field in part caused by the large size of Sberbank and by the 100 percent guarantee of household deposits for state banks.}

- $\quad$ Since January 11, 2005 Sberbank has been part of the deposit insurance system. Thus, as of January 1, 2007, from the standpoint of guarantees for household deposits Sberbank is operating under the same conditions as other lending institutions that are participants in the deposit insurance system. 
Hold Sberbank to the same standards as other banks operating on a fully commercial basis with a hard budget constraint.

- $\quad$ Current legislation in the Russian Federation and regulatory acts of the Bank of Russia establishes the same requirements for all lending institutions operating in the country, including Sberbank.

Develop medium-term options for Sberbank in the context of a comprehensive strategic review.

- $\quad$ Sberbank was operating in accordance with the Conceptual Framework for the Development of Sberbank of Russia up to 2005, which it devised and which was approved by the Sberbank Supervisory Board, with the participation of representatives of the Bank of Russia, and by the annual general shareholders' meeting.

Close (or restrict licensing to no longer allow soliciting of household deposits) those banks which are nonviable, overburdened with connected lending, or in transgression of supervisory norms.

- In 2006, the Bank of Russia revoked licenses of 62 lending institutions compared with 40 in 2005.

Ensure that only viable banks enter into the proposed mandatory deposit insurance scheme.

- $\quad$ The Law on Deposit Insurance requires that banks participating in the deposit insurance system meet the following requirements: (i) minimum capital adequacy levels, (ii) fit and proper bank management and its operational and risk management, (iii) minimum profitability levels, and (iv) minimum liquidity levels. All bank accepting retail deposits must be a member of the deposit insurance system. As of January 1, 2007 there were 934 banks participating in the mandatory deposit insurance system. 


\section{Payment Systems}

\section{Adopt a revised payments system concept paper and submit it to a limited period of public consultation before the launch of a properly managed and resourced project.}

\section{Develop an RTGS system operating on centralized principles, with appropriate liquidity and operational risk management features.}

- $\quad$ The Plan of Measures for 2007 for the Establishment of a Real-Time Gross

Settlement System of the Bank of Russia (RTGS System) has been drafted and approved, and it sets forth a mandatory list of measures and deadlines for their implementation. Specifically, objectives were defined in Regulation No. 303-P "On the Real-Time Gross Settlement System of the Bank of Russia" of April 25, 2007; rules for the performance of settlements through the RTGS were set in Directive No. 1822-U "On the Procedure for Effecting Payments and Performing Settlements in the Real-Time Gross Settlement System of the Bank of Russia" of April 25, 2007; and identification codes were established in Directive No. 1824-U "On Amendments to Bank of Russia Regulation No. 225-P” of May 6, 2003 “On the Directory of Bank Identification Codes of Settlement Participants Effecting Payments through the Settlement Network of the Central Bank of the Russian Federation (Bank of Russia)" of May 2, 2007.

A number of steps have been taken to implementation of the RTGS system. Specifically:

- A centralized technical infrastructure was established that contains fail-safe and crash-proof components and regional branch offices of the Bank of Russia;

- $\quad$ introduction of an electronic settlement system (more than 99 percent of payments are effected using electronic technology);

- $\quad 97.2$ percent of Bank of Russia branch offices participating in the electronic settlement system;

- $\quad$ introduction of uniform formats for Bank of Russia electronic bank messages; and

- $\quad$ standardization of accounting and operating systems for the processing of bank information. 


\section{Corporate Governance}

\section{Increase transparency of ultimate ownership and control structures.}

- $\quad$ The Bank of Russia strengthened oversight of corporate governance through enactment of the deposit insurance system. Legislation was also amended, lowering the threshold for the acquisition of stock in lending institutions that requires notification of the Bank of Russia from 5 percent to 1 percent.

\section{INSOLVENCY REGIME}

\section{Establish a new creditor reporting agency to promote greater access and transparency to credit information on borrowers.}

- $\quad$ Federal Law No. 218-FZ “On Credit Histories” was adopted on December 30, 2004. It defines the procedure for the formation, compilation, and presentation of credit histories (credit reports), requirements for credit bureaus, and the rights of a subject of a credit history. There are currently 23 credit bureaus in Russia that have been entered in the state register of credit bureaus, the majority of which are located in Moscow and St. Petersburg.

- $\quad$ The Federal Law does not establish any restrictions on the total number of credit bureaus that may be established, but it introduces a number of requirements that credit bureaus must meet. Manager and deputy managers must not have been convicted of economic crimes and partners need to be fit and proper.

- A credit bureau need not obtain a special license to operate but is required to have a license to perform operations related to the technical protection of confidential information. The Federal Service for Technical and Export Control (FSTEC) is responsible for licensing operations related to the technical protection of confidential information. 